\title{
MISCONCEPTIONS ABOUT THE CALIPHATE IN ISLAM
}

\author{
Thesis \\ Submitted to \\ The College of Arts and Sciences of the \\ UNIVERSITY OF DAYTON
}

In Partial Fulfillment of the Requirements for

The Degree of

Master of Arts in English

By

Wayel Azmeh, MD

Dayton, Ohio

May, 2016

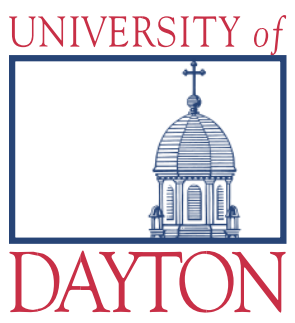




\section{MISCONCEPTIONS ABOUT THE CALIPHATE IN ISLAM}

Name: Azmeh, Wayel, MD

APPROVED BY:

Andrew Slade, Ph.D.

Thesis Advisor

Associate Professor, Chair, Department of English

Kitayun Marre, Ph.D.

Committee Member

Professor Emerita, Department of English

Bryan A. Bardine, Ph.D.

Committee Member

Associate Professor

Director of Teaching Assistant Training

Department of English 
(C) Copyright by

Wayel Azmeh

All Rights Reserved

2016 


\section{ABSTRACT \\ MISCONCEPTIONS ABOUT THE CALIPHATE IN ISLAM}

Name: Azmeh, Wayel, MD

University of Dayton

Advisor: Dr. Andrew Slade

Three common misconceptions about the caliphate in Islam are explored: 1) That the caliphate is one centralized government embodying one unified Muslim community living in peace, justice and luxury until $1924 \mathrm{CE}$; 2) That there has been no more than one caliph at a given time.; 3) That Islam has a specific divine blueprint for a system of governance called the caliphate system, mandated by God. Anyone who abandons this blue print abandons Islam. The essay starts with the role the caliphate played in agendas of Islamic movements over the last hundred years followed by a historic discussion addressing the first two misconceptions. The third misconception is addressed through a linguistic, Qur'anic, and historical analysis of the word "caliphate." The fact that neither the Qur'an, nor the Prophet saw himself as a head of state is explored and the misappropriation of the word "constitution" to replace the word "pact" in "the pact of Medina" is pointed out. A simple classification of three types of "caliphates" is suggested, emphasizing the wide range of connotations it conveys. Finally, counterarguments using the Qur'an and hadith are addressed. The essay concludes: what 
makes a state Islamic are not name nor its structure, but rather its orientation towards Qur'anic ethical values

Keywords: Caliphate, Constitution of Medina, Islamic state, Islamic government, Islamic Empire, Islamic history 


\section{From Odysseus to Penelope,}

Whose loving spirit and sharp wit nourish the heart and reinvents the dream. You are the reason why Odysseus proceeds without fear.

To Ramzieh, the spirit of my soul. 


\section{ACKNOWLEDGEMENTS}

I would like to express my gratitude to Dr. Andrew Slade, my thesis advisor, and department chair. Dr. Slade's presence has touched me from the first day I walked into the English department when I was still trying to decide about enrolling as a graduate student. His enlightening guidance and patient critique were instrumental in bringing up my research findings from the depth of history to the shore of contemporary life. His emphasis on the rhetorical component and his willingness to block time for joint, in-depth rhetorical readings and discussions made this thesis a landmark in my on-going academic journey. He was able to make himself available to me any time in spite of his heavy commitments as the chair of the English department. Such is the spirit of academia that time can never aspire to defy since the days of Socrates.

I would also like to express my deepest gratitude to my mentor, Dr. Kitayun Marre. Dr. Marre does not just teach and mentor, she inspires. For education and guidance are a spirit she embodies as an unpretentious living philosophy. She gave me confidence and helped me overcome the psychological impediments I was struggling with when I first enrolled as a graduate student at the English department. Dr. Marre is to me what Athena is to Odysseus in Homer's classical epic I was privileged to study with her in the spring of 2015. Dr. Marre spontaneously assumed the task of guiding me 
through my academic journey for the long haul. A dedication her retirement could not tamper. She always uncovers a pertinent reference whenever I need further reading on a difficult question. She generously gave me many published treasures and hand-written notes she collected over more than fifty years. In the course she taught on Joyce, she led me to reappraise literature as the all encompassing center stage of life. Her course on English romantic poets fostered my newly found openness, propelling me into a new horizon in novel ways, ways I could only imagine before I took Dr. Marre's courses. It became clear to me that philosophy, history, poetry, and science are unmistakably mere facets of one human discipline. The barriers are arbitrary, and literature captures them all in ways that no other discipline can. It is hard for me to visualize my graduate studies at the English department without Dr. Marre's expert support and inspiration. Her knowledge, caring spirit, and unpretentious living example will continue to guide me for the rest of my life. It is thanks to Dr. Marre that this thesis is able to grow and transform itself in ways that would have been impossible without her tireless dedication and exemplary patience. Dr. Marre's astute guidance never waivered from the inception of this work until its completion.

Finally, I would like to thank Dr. Bryan Bardine for what he has done for me as a great role model of a compassionate teacher. Dr. Bardine's easy going and supportive attitude is an exemplary one that I will always carry in me. He taught me a lot and molded me into the College teacher I am now becoming. His door is always open, and his welcoming smile is always the first step in melting out whatever difficulty I might be seeking to resolve. I am very proud to call Dr. Bardine a mentor and a friend. 


\section{TABLE OF CONTENTS}

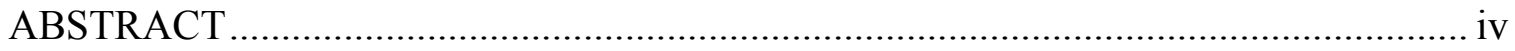

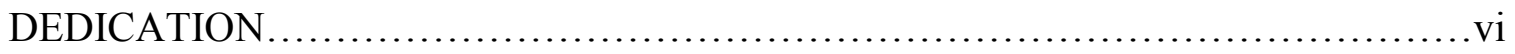

ACKNOWLEDGEMENTS ............................................................................ vii

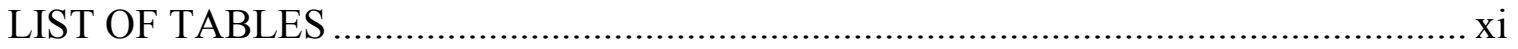

LIST OF MAPS AND CHARTS ...........................................................................

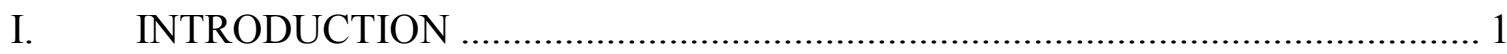

II. AN OVERVIEW OF THE CALIPHATE .................................................. 3

III. POLITICAL PARTIES CALLING FOR THE RESTORATION OF THE

CALIPHATE SYSTEM IN THE TWENTIETH CENTURY AND BEYOND ............... 6

IV. A VAST BUT FRAGMENTED ('ABBĀSID AND OTTOMAN) CALIPHATE . 9

V. MORE THAN ONE CALIPHATE EXISTED SIMULTANEOUSLY ................ 17

VI. DOES THE RELIGION OF ISLAM DICTATE A CALIPHATE?...................... 24

A. There is no caliphate in the Qur'an .................................................................. 25

B. The Prophet never viewed himself more than a messenger of God and

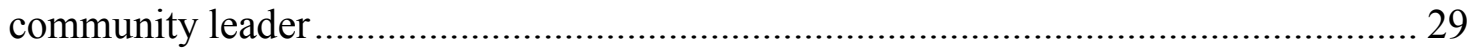

C. The political institution of the Caliphate emerged after the death of the Prophet

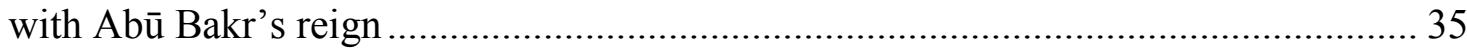


VII. COUNTER ARGUMENTS ERRONEOUSLY CLAIMING ISLAM MANDATES

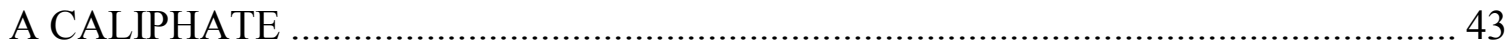

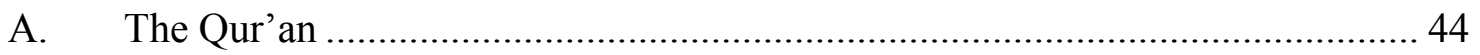

B. Hadiths (reports of sayings) of the Prophet................................................... 45

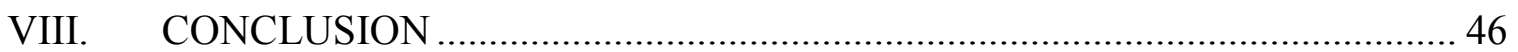

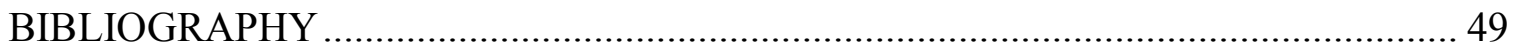

GLOSSARY 


\section{LIST OF TABLES}

TABLE 1: An approximate number of independent Muslim dominions every

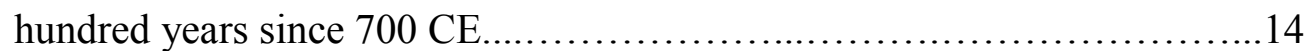

TABLE 2: Distances and travel times from 'Umar's capital in Medina to the periphery of his caliphate.............................................

TABLE 3: Caliphates 632-2015 CE............................................. 18

TABLE 4: Three different types of caliphate systems...............................22 


\section{LIST OF MAPS AND CHARTS}

MAP 1: The Muslim Caliphate at the end $660 \mathrm{CE}$, and then at $750 \mathrm{CE} . . . . . . . . . .11$

MAP 2: The 'Abbāsid caliphate in the ninth century CE........................11

CHART 1: Approximate number of independent Muslim dominions every 100 years..14

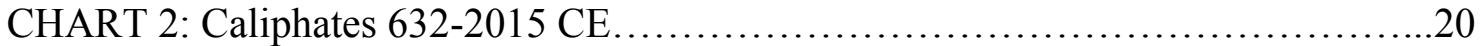

CHART 3: A snapshot depicting the number of caliphate systems every 100 years

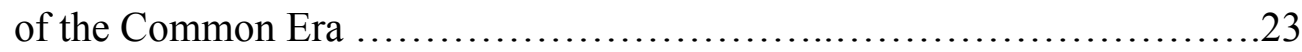




\section{MISCONCEPTIONS ABOUT THE CALIPHATE IN ISLAM ${ }^{1}$}

\section{INTRODUCTION}

In June 2014, the militia known as ISIS-Islamic State in Iraq and Syria announced the re-establishment of the caliphate. ${ }^{2}$ This is happening ninety years following the official end of the symbolic title of the Ottoman caliphate in $1924 \mathrm{CE}$. The caliphate has recently been described by ISIS spokesman as "the dream in all the Muslims' hearts" and "the hope of all jihadists." ${ }^{3}$ This romantic symbol of the caliphate attracts young Muslims from all over the world via the Internet to this so-called Islamic state. Abu Mohamed al-Adnani, the spokesman for ISIS declared: "The legality of all emirates, groups, states and organisations becomes null by the expansion of the caliph's authority and the arrival of its troops to their areas.... Listen to your caliph (sovereign) and obey him. Support your state, which grows every day."4

Current caliphate advocates paint a sacralized image of the caliphate based of three claims:

1. That the caliphate is one centralized government embodying one unified Muslim community living in peace, justice and luxury until Mustafa Kemal Atatürk abolished in $1924 \mathrm{CE} . .^{5}$ Therefore, ISIS claims to be restoring lost power and justice to Muslims all around the world by bringing the caliphate back to life. 
2. That there has been no more than one caliphate at a given time, only one caliph at a time.

3. That Islam has a specific divine blueprint for a system of governance called the caliphate system, mandated by God. Anyone who abandons this blue print abandons Islam.

But before we start, I would like to state that the discussion of the institution of the caliphate here is limited to the Sunni tradition upon which current political investments in the caliphate seem to thrive (Sunnis happen to constitute $87-90 \%{ }^{6}$ of Muslims).

Therefore, the the definition of the Caliphate (khilafa in Arabic) is "the office or dominion of a Caliph."7 It is common to refer to medieval Muslim polity as a whole as the caliphate. ${ }^{8}$ Caliph (khalifa in Arabic) means literally a deputy or a successor. Caliph is the Muslim sovereign title of the middle ages. The full title is Khalifat Rasūl Allah (successor of the messenger of God). The title emerged immediately after the death of Prophet Muhammad in 632 CE. ${ }^{9}$ The Prophet's companions met then and designated a successor for the Prophet in his own capacity as a leader of the recently founded Muslim community in Medina. The first four caliphs were chosen by acclamation and were therefore called the rightly guided caliphces (al-Khulafa' al-Rashidūn); they are in chronological sequence: Abū Bakr (d $634 \mathrm{CE})$, 'Umar (d 644$)^{*}$, 'Uthman (d $\left.656 \mathrm{CE}\right)$, and 'Ali (d $661 \mathrm{CE}) .^{10}$

\footnotetext{
* I have followed the Encyclopedia of Islam standard for Arabic transliteration in this essay. 'U and 'A in "'Umar, "Uthman, and "Ali correspond to the Arabic letter "ع."
} 
The jurists asserted that the caliph is the successor of the messenger of God, and in no sense the successor of God. The caliph is not the deputy of God; he is " the custodian of the moral and intellectual heritage of the Prophet, in his double capacity as founder of the faith and creator of the Islamic polity and community, but not in his spiritual office as Prophet and bringer and interpreter of God."11

Amir al-Mu'minin (the commander of the believers in Arabic) is another exclusive reference to the caliph. It is attributed to Omar bin al-Khattab, the second caliph (sovereign) who decided that the title Amir al-Mu'minin would be easier than the title khalifa of the khalifa (successor of the successor) of the Prophet of God, which will grow too long with the accumulation of successors to the office over time. ${ }^{12}$

My thesis focuses on exploring and critiquing the three above-mentioned claims about the caliphate system. I will start by introducing the subject to the reader with a brief synopsis of the history of the caliphate system, followed by a description of some of the political movements in the twentieth century that called for the restoration of the caliphate system. I will then proceed to critically discussing the three claims: that there has been only one caliph at a time governing all Muslims, that the caliph always governed a vast territory with exemplary justice, and that Islam dictates a blue print of a political system called the caliphate. This will be followed by addressing two possible objections from Islamic sources and then the conclusion.

\section{AN OVERVIEW OF THE CALIPHATE}

After the death of the Prophet Muhammad in 632 CE, the Prophet's companions met and designated a successor for the Prophet as a leader of the recently founded 
Muslim community in Medina. The first four caliphs were chosen by acclamation of the leadership confirmed by the pledge of the rest of the population. The first four caliphs: Abū Bakr, 'Umar, 'Uthman, and 'Ali were therefore called the rightly guided caliphs (al-Khulafa al-Rashidun). ${ }^{13}$

In 661, a civil war that lasted five years culminated in the assassination of the fourth caliph Ali who belonged to the Prophet's Hashemite clan of Quraysh. Mu'awiyah, ${ }^{14}$ who belonged to the competing Umayyad clan ${ }^{15}$ acceded to the post and ruled for 19 years from his capital in Damascus. Then Mu'awiyah designated his son as a Caliph by the force of the sword. Thus a new kind of caliphate system, one that is hereditary and limited to one clan, the Umayyads started. In the year $750 \mathrm{CE}$ the 'Abbāsids lead a successful revolt, took over the caliphate and moved the capital to Baghdad. ${ }^{16}$

The 'Abbāsid caliphate ruled between $750 \mathrm{CE}$ and $1258 \mathrm{CE}$ when it ended at the hands of the Mongols. The Mongols were invader tribes from east Asia who sacked Baghdad and killed the caliph. The Mamluks, a regime controlled by slave soldiers in Egypt ${ }^{17}$ defeated the Mongols in Palestine and checked their expansion before they were able to reach Egypt. An 'Abbāsid prince fled to Cairo, he was welcomed and honored by the Mamluk Sultan (highest ruler). For the three years that followed 1258 CE there was no caliph or caliphate. In $1261 \mathrm{CE}$, in Cairo, the 'Abbāsid prince was given the title of caliph. It was an honorary title devoid of political power and responsibility. This merely symbolic caliph position lasted until $1517 \mathrm{CE}$ when the Ottomans entered Egypt, thus ending the Mamluk reign. ${ }^{18}$ 
The head of the Ottoman Empire, the Ottoman sultan, was not referred to as caliph until $1774 \mathrm{CE}$ when this title was used in the treaty between Catherine the empress of Russia and Abd al-Hamid I the Ottoman sultan. ${ }^{19}$ The Ottomans continued to use this title of caliph later on to assert their influence on Muslims in Arab countries and territories they lost in Europe. ${ }^{20}$ The title of caliph was "formally asserted in the first Ottoman constitution of $1876 \mathrm{CE}$. It remained official Ottoman doctrine until the caliphate system was abolished by the Turkish Republic in 1924 CE."21

The above-mentioned events in the history of the caliphate took place in the Arabian Peninsula, Syria, Iraq, Egypt, and Turkey. However, the establishment of a caliphate system was not limited to this central area of the Muslim world. Other caliphate systems existed simultaneously with the 'Abbāsid caliphate such as: Almohads $^{22}$ (1150-1269 CE) in Spain and in the area of today's Morocco, and the first Zaydis $^{23}$ (943-1018 CE) in Yemen. Other caliphates will be mentioned in section IV below. Many writers seem to focus on the legacy of the Ottoman caliphate probably because it was considered an independent super power at a time when most Muslim countries were under a colonial European mandate. This has contributed to eclipsing the other smaller caliphates of a more limited geographical expanse, many of which were far away from the central lands of Islam. Therefore, contrary to the commonly held view, the caliphate has not been a monolithic system, encompassing all Muslim lands the way many imagine it to be for most of its history. We will go over this misconception of "one caliphate over a vast unified land" later in this essay. But before doing that, a review of the history of the caliphate in the twentieth century will help us 
better understand the background on which the three common misconceptions of the caliphate took place.

\section{POLITICAL PARTIES CALLING FOR THE RESTORATION OF THE CALIPHATE SYSTEM IN THE TWENTIETH CENTURY AND BEYOND}

The abolition of the Ottoman caliphate had long lasting repercussions in the Middle East. Some Muslims outside Turkey accepted abolishing the title of caliph as part of modernity. Ali Abdel Razik, for example, who was an Egyptian judge wrote a controversial book in $1923 \mathrm{CE}$ called al-Islam wa uṣūl al-ḥukm [Islam and the Rules of Governance]. Abdel Razik, claimed that the Prophet's message limits its concerns to theology, ethics and ritual. Abdel Razik stressed that the Prophet never discussed a caliphate system and did not found a government. This opinion was rejected by the majority in the Muslim world at the time and led to the expulsion of Abdel Razik from the hay'at kibār al- 'Ulama' [the body of Great Religious Scholars]. ${ }^{24}$ Four years later, the dream of restoring the caliphate was part of what triggered the formation of the Muslim Brotherhood movement by Hasan al-Banna in $1928 \mathrm{CE}^{25}$

Hasan al-Banna, the founder of the Muslim Brotherhood wrote in 1938 CE:

The brothers [of the Muslim brotherhood] believe that the Caliphate is symbolic of Muslim unity, and a manifestation of the attachment among their nations. It is a rite that Muslims should contemplate and be concerned with, for the Caliph is commissioned to enact many of God's stipulations...the Muslim brothers therefore make the idea of Caliphate and the work to re-establish it at the top of their agenda." $" 26$ 
Hasan al-Banna wrote a detailed list of suggestions to modify the Egyptian elections law to make it more representative of the people, and in doing so his action was no different than the action of any committed democrat. This is a far cry from some contemporary fundamentalists sixty years later. ${ }^{27}$ There were similar reactions to the abolishment of the Ottoman caliphate in other parts of the Muslim world such as the Indian subcontinent but I will not discuss them here for reasons of space.

Hizb al-Tahrir al-Islami (the Islamic Party of Liberation) ${ }^{28}$ started in Palestine in 1948, although it was not officially announced until 1953 CE. Its founding premise was that Arab society is an Islamic society even though it included non-Muslim Arabs such as Christians and adherents to other faiths. According to the Tahrir party, Arabs need to invest in Islam in order to liberate Palestine from the newly founded state of Israel. The focus of the Tahrir party was to reform society as a whole, rather than individuals. The central idea is that "...the caliphate system [namely] re-establishing the caliphate is the greatest feat. They [Tahrir party ] believe that as soon as the caliphate is re-established everything will be fixed." 29 The founders of the Tahrir party denounced secular capitalistic democracy as contrary to Islam because it separates religion from state, transferring the authority of law giving from God to the people. The Tahrir party founders even went further, using their interpretation of divine authority to reject freedom of conscience, freedom of religion, and individual freedom. Nevertheless, they excluded violence as a viable means to achieve their stated goal of re-establishing a caliphate. They explained shunning violence by saying that their modern circumstances were akin to those of the first 13 years that the Prophet spent in Mecca, before his 
migration to Medina. ${ }^{30}$ In those earlier days of Islam, the Prophet prohibited his disciples from any physical retaliation, including self-defense. ${ }^{31}$

In the 1950s, one of the Muslim Brotherhood intellectuals in Egypt, Sayyid Qutb wrote his book Ma'alim fi al-tarik (Sign posts along the way). In it he envisioned jihad, ${ }^{32}$ not as a mean of defense, as Hasan al-Banna did, but as a mean to carry the message of Islam to the world. This was a radical departure from the approach the Muslim Brotherhood founder, Hasan al-Banna took. The Qutb approach was embraced by a fraction of the group. This new ideology, combined with harsh crackdown on political Islam inspired some Islamists to create a separate new group: al-Jihad al-Islami (Egyptian Islamic Jihad) in the 1970s. ${ }^{33}$ al-Jihad al-Islami achieved notoriety for killing tourists in Egypt. Violence escalated and in 1981 CE Islamic Jihad assassinated the president of Egypt Muhammad Anwar al-Sadat. Their leader was an Egyptian cleric Omar Abd al-Rahman who lived in the United States. He is serving a lifetime sentence in prison for co-conspiring in the assault on the world trade center in New York in 1993 CE. al-Jihad al-Islami group circulated a book called al-Faryda al-Gha'iba (the missing obligation). In that book, "Jihad is emphasized as 'the only way to return Islam and build the monument of Islam anew... 'a tyrant will not be eliminated, but by the sword.' Islam will come back and will conquer Rome, as it conquered Constantinople [Istanbul in today's Turkey]. ${ }^{34}$

Therefore, the sense of defeat in the Arab world in the wake of the dismantling of the Ottoman caliphate and the subjection of many Arab countries to western colonial powers fueled the longing for a glamorized caliphate that would free and unite the Arab countries in the Middle East. The displacement of hundreds of thousands of Palestinians 
on the wake of the creation of the state of Israel in $1948 \mathrm{CE}$ added fuel to that longing for the caliphate as articulated by the Tahrir party. And then came the harsh oppression by totalitarian Arab regimes as we saw in Egypt and other Middle Eastern countries that radicalized some Islamists and triggered an unprecedented kind of terror by the Islamic Jihad in Egypt. The ground was now fertile for even more extremist groups. Then came the invasion of Iraq and the dismantling of the central government of Iraq that sparked the new wave of extremism. And when the chaos of the Syrian civil war set in ISIS proclaimed the caliphate on June the $29^{\text {th }}, 2014$ CE.

Armed with the brief review above of what the caliphate was and what has become of it recently establishes the relevance of the concept of the caliphate to current world events. For the three common misconceptions about the caliphate are exploited in radicalizing Muslim youth all around the world. We shall start with examining the claim that the caliphate was one vast centralized dominion for most of Islamic history, then we will tackle the assumption that there was no more than one caliphate at one period of time, and we will finally critically examine the assumption that the caliphate is mandated by the religion.

\section{A VAST BUT FRAGMENTED ('ABBĀSID AND OTTOMAN) CALIPHATE}

As we have seen, the reign of the last of the four rightly-guided-caliphs ended in civil war with the accession of Mu'awiyah as the first caliph of the Omayyad dynasty in 661. The Umayyad dynasty was an expanding centralized Empire that ended in 750 at the hands of the 'Abbāsids. The 'Abbāsid dynasty started as a vast Empire, that quickly fragmented into independent dominions claiming only nominal allegiance to the 
'Abbāsid caliph. The 'Abbāsid rule ended at the hands of the Mongols in 1258. As we will see below, the 'Abbāsid caliph offspring lived in a palace in Egypt as a symbol, with no involvement in governance which was practiced by the Mamluk slaves. The Ottoman dynasty started 1293 in Turkey and expanded slowly. It was only in a 1774 treaty with Russia that they used the title caliph and kept it until the abolition of the caliphate in Turkey in 1924. The Ottoman caliphate was as fragmented as the 'Abbāsids' with only nominal allegiance of many independent dominions on its territories.

When people contemplate the caliphate, they often amalgamate a composite picture of the caliphate of 'Umar the second rightly guided caliph to reign after the Prophet's death ('Umar reigned 634-644 CE) ${ }^{35}$ with that of Hārūn al-Rashīd the fifth 'Abbāsid caliph (reigned 786 to $809 \mathrm{CE}$ ). ${ }^{36}$ The caliphate of 'Umar exemplifies a strong, burgeoning centralized empire with its self-negating ruler 'Umar, meting out justice and insuring equality of all citizens. 'Umar kept tight control over his governors and the caliphate enjoyed unity of its people and uniformity in governance. ${ }^{37}$ The caliphate included at that time Syria, Persia (Fars), and Egypt (see map 1 below). 'Umar had no palace or office; he had no personal secretary or even a bodyguard. 'Umar governed from the austere Prophet's mosque in Medīna, the capital of his caliphate. There were no barriers separating the caliph (sovereign) from any of his citizens in Medina who knew him closely and respected him for his moral authority and example. ${ }^{38}$ We are told that when the Persian (Farsi) general al-Hurmuzan went to Medina to meet with 'Umar, he had difficulty recognizing him as the caliph (sovereign) because of 'Umar's simple attire and humility. ${ }^{39}$ 


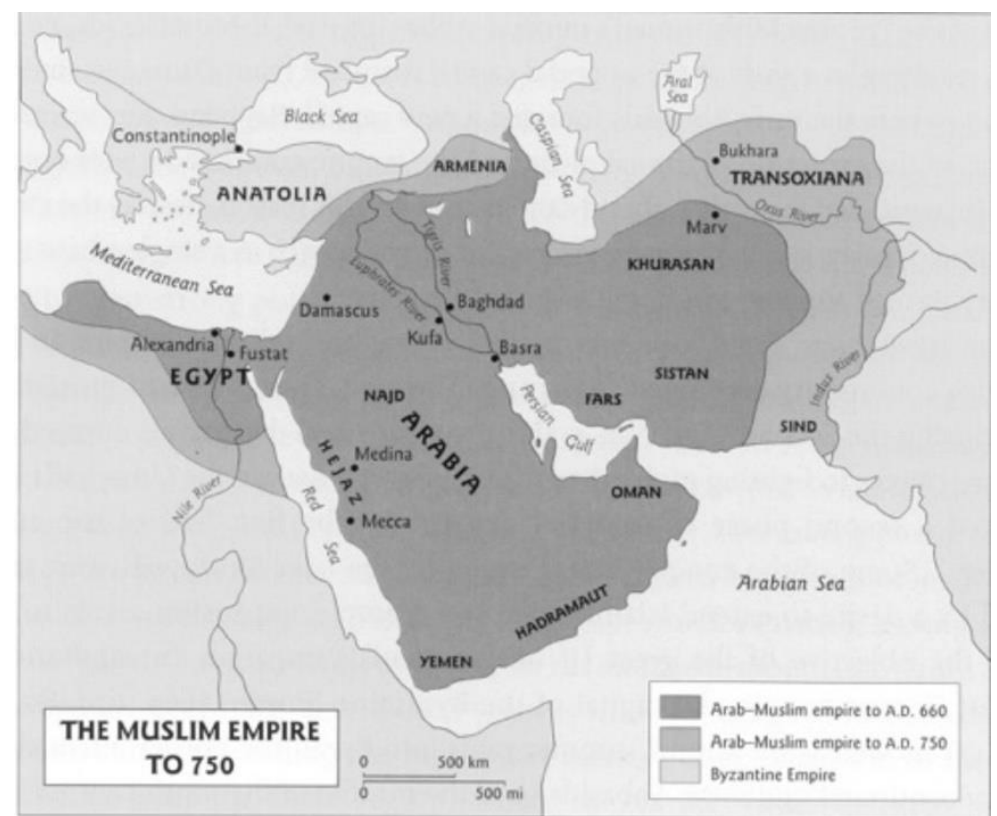

Map 1 The Muslim caliphate (polity) at the end of 660, and then 750 CE. ${ }^{40}$

The following map shows the large territory of the 'Abbāsid caliphate between the eights and eleventh centuries of the common era.

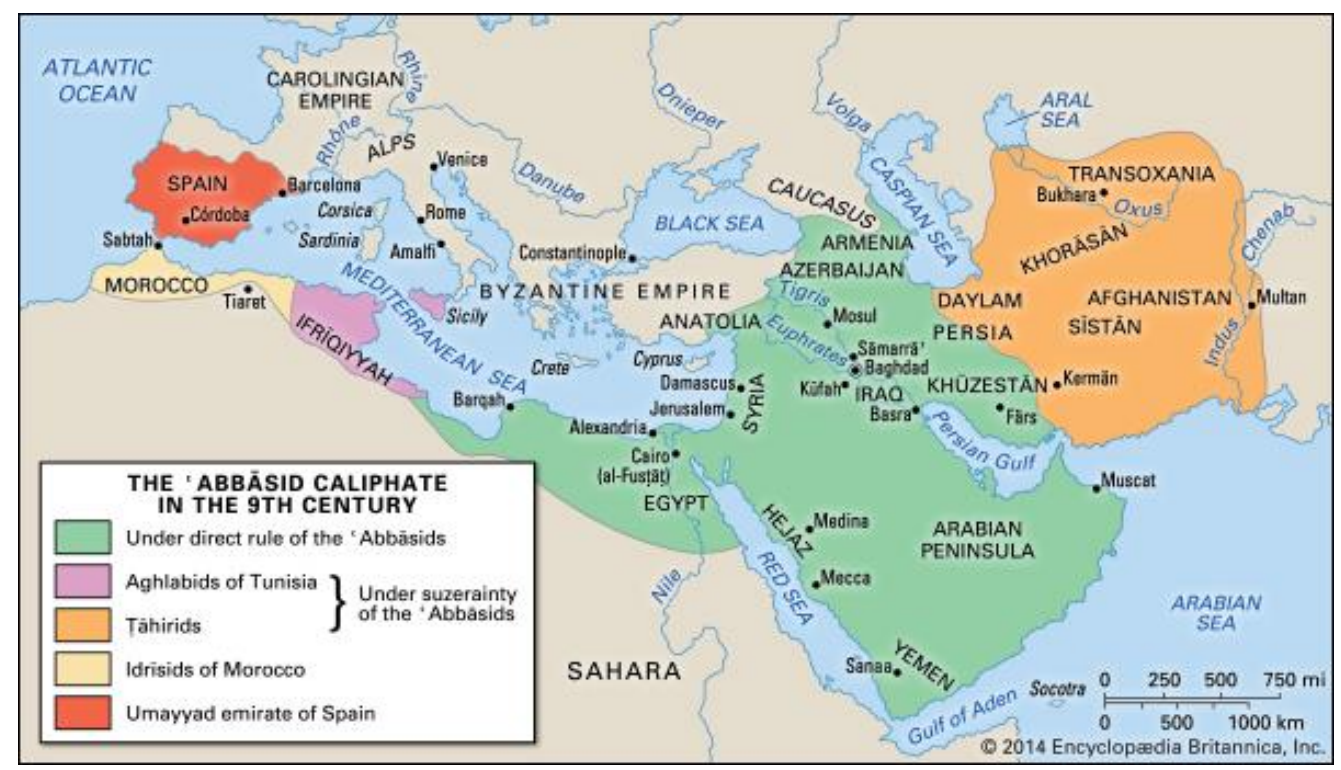

\section{Map 2 The Abbāsid caliphate in the nineth century $\mathrm{CE}^{41}$}

The situation was quite different 154 years later in 786 CE when Hārūn al-

Rashīd, the fifth 'Abbāsid caliph (d 809) took on the post of caliph in the capital 
Baghdād. The caliphate at that time of Harūn al-Rashīd was much larger than what it was at the time of 'Umar; see map 2 above. It included all of north Africa, and extended east beyond the Indus river, and north beyond Persia—Fars. It was the vastness of the 'Abbāsid caliphate and the lack of modern means of communication that probably dictated unavoidable decentralization which quickly became de facto independence. Spain was an independent Umayyad kingdom off limits to the 'Abbāsids. The offspring of the only Umayyad prince to escape the massacre the 'Abbāsids committed against the Umayyads in 750 CE governed Spain then from Cordoba. Spain was not declared as a new caliphate until 912 CE. Distant north Africa as we see in map 2 was completely detached: the Rustamids' a dynasty that ruled an area including today's Tunisia between 778-909 CE; ${ }^{42}$ the Idrīsīds, a dynasty that ruled Morocco between 789-985 CE ${ }^{43}$; and the Aghlabīds who ruled southern Algeria between 800-909 CE. ${ }^{44}$ The 'Abbāsid Caliph granted the Aghlabīds the privilege of nominating their children as successors and they paid a yearly tribute to the "Abbāsid caliph in Baghdad. ${ }^{45}$ Map 2 depicts various independent dominions with only nominal loyalty to the 'Abbāsid caliph at different times. Other dominions were totally independent and hostile to the "Abbāsids including the Umayyads in Spain (Umayyads II), ${ }^{46}$ the Rustamids who belonged to an opposing Sect, and the hostile state of the Karmatians (Qarmatians) who are a different extreme sect that ruled eastern Arabia between $899-1067 \mathrm{CE} \cdot{ }^{47}$

Contrary to the austere appearance of 'Umar, the appearance of the 'Abbāsid caliphs was unmistakable due to their overindulging luxury. The 'Abbāsid caliphs, just as their Umayyad predecessors lived in sumptuous palaces and enjoyed the most extravagant life style known at the time. We are told that when Charlemagne ${ }^{48}$, the 
emperor of the Franks ${ }^{49}$ in Europe sent two embassies to Hārūn al-Rashīd, Charlemagne in return received sumptuous gifts of a kind unknown to the west at that time. ${ }^{50}$

Therefore, amalgamating the exemplary justice of 'Umar with the vast territory of Harūn al-Rashīd leaves out two important details: first, 'Umar's centralized caliphate was less than half the size of Harūn al-Rashīd's. Second, while Harūn had no control on the majority of his vast caliphate. Third, in the application of justice, most Muslims agree that no ruler can be compared to the four rightly guided caliphs, particularly 'Umar in the fairness of their rule. Two classical scholars, Ibn Taymiyya, a Muslim jurist (d $1327 \mathrm{CE}) ;{ }^{51}$ and Ibn Khaldūn, a Muslim historian (d $\left.1406 \mathrm{CE}\right),{ }^{52}$ declared that the caliphate had seized to exist after the first four rightly guided caliphs after. To both Ibn Taymiyya and Ibn Khaldūn the caliph post became an inherited office instead of one to which the community selects based on merit.

Table 1, below shows the number of independent Muslim dominions every hundred years from $700-2000 \mathrm{CE}^{53}$. The information in table 1 is depicted as a graph in chart 1 that follows. 
Table 1: An approximate number of independent Muslim dominions every hundred years since $700 \mathrm{CE}$. Note: that in year $700 \mathrm{CE}$ hundred the Umayyad I caliphate had a centralized government in Damascus with no independent states. Also note that, in 1900 CE, most Muslim states were colonies of western countries such as France, Britain, Spain, and Belgium which explains the drop in the number of independent states in 1900 as the table above shows. ${ }^{54}$

\begin{tabular}{|c|c|}
\hline Year & Independent Dominions Excluding Caliphates \\
\hline $700 \mathrm{CE}$ & 0 \\
\hline $800 \mathrm{CE}$ & 4 \\
\hline $900 \mathrm{CE}$ & 9 \\
\hline $1000 \mathrm{CE}$ & 8 \\
\hline $1100 \mathrm{CE}$ & 10 \\
\hline $1200 \mathrm{CE}$ & 10 \\
\hline $1300 \mathrm{CE}$ & 14 \\
\hline $1400 \mathrm{CE}$ & 14 \\
\hline $1500 \mathrm{CE}$ & 20 \\
\hline $1600 \mathrm{CE}$ & 13 \\
\hline $1700 \mathrm{CE}$ & 13 \\
\hline $1800 \mathrm{CE}$ & 17 \\
\hline $1900 \mathrm{CE}$ & 3 \\
\hline $2000 \mathrm{CE}$ & 49 \\
\hline
\end{tabular}

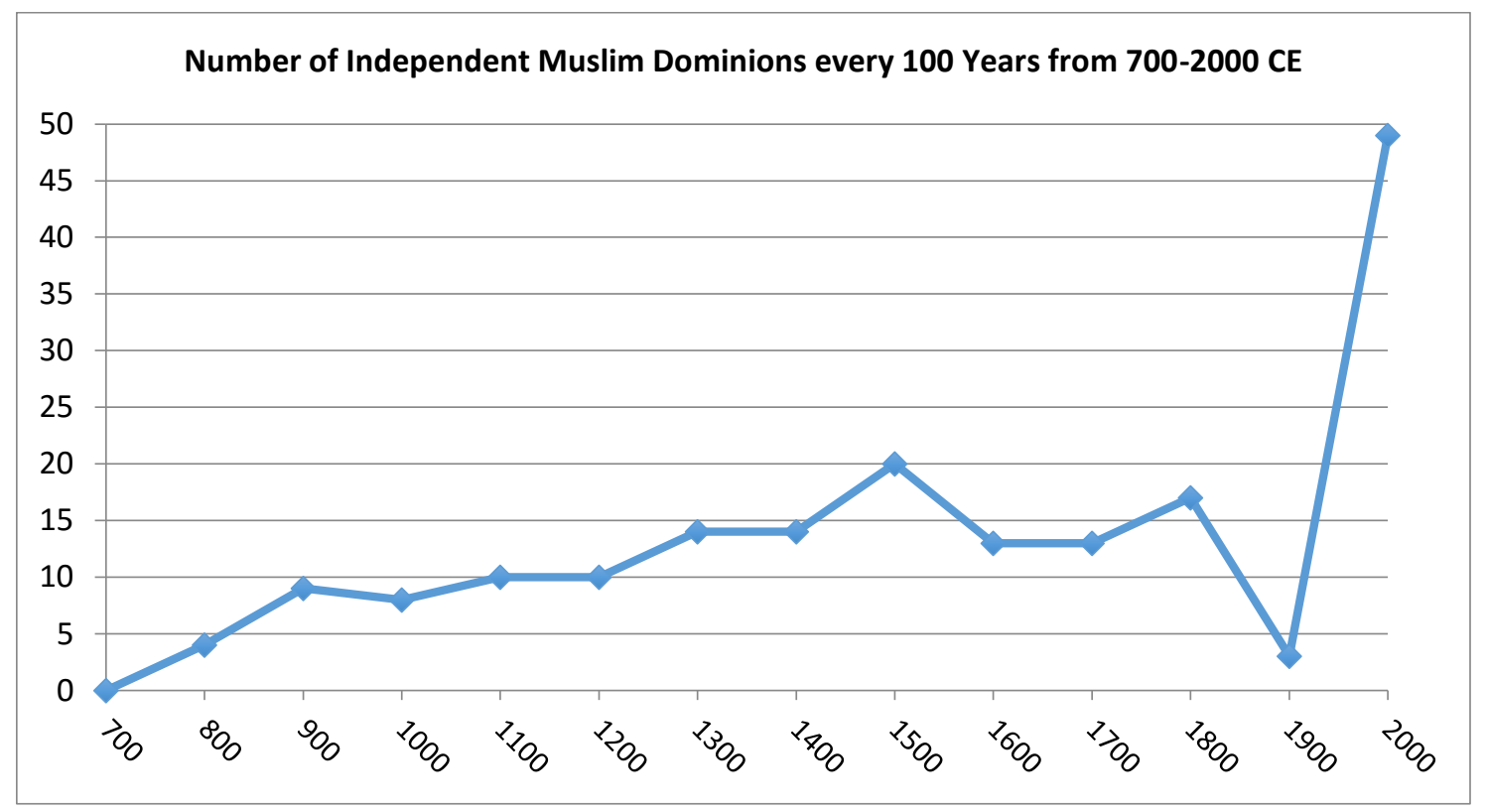

Chart 1: Approximate number of Independent Muslim dominions every 100 years 
The information presented above shows that the centralized caliphate lasted only 118 years after the death of the Prophet in 632 CE. This includes the four rightly guided caliphs until 661 CE followed by the Umayyad I caliphate in Damascus until 750 CE. A centralized caliphate was never possible again. In fact, it is quite remarkable that a centralized government was able to hold together a land extending from Spain and Morocco in the West to India in the East for 118 years. One can speculate that it was possible for this unique historical period to be sustained for that long only because defeated Persians were in a transition defining and redefining the limits for their assimilation into Arab and Islamic culture. For the wake of the devastating crush of the Persian Empire with its rich culture was hard to match in history.

The idealized image of a caliphate the size of the 'Abbāsid's, yet unified under a central exemplary and just government is inspiring to Muslims, but it never existed in reality that way. For, even if one is to dream one day that 'Umar who governed in Medina 634-644 CE would miraculously come back to life 106 years later to govern on top of the large, sprawling 'Abbāsid caliphate from its new capital in Baghdad at 750 $\mathrm{CE}$, 'Umar would not be able to do it unless he would be willing to change his style of governing in a radical way that would make it difficult for us to recognize him. For it is not only 'Umar's outstanding qualities that made his rule exemplary, but also the cultural environment in Medina that enabled the towering figure of 'Umar to rule the way he did.

The composition of the citizens in Baghdad had a significant element of nonArabs and non-Muslims, including not only Christians and Jews, and Sabians, ${ }^{55}$ but also Zoroastrians ${ }^{56}$ Buddhists and adherents to other religions unknown in the Arabian 
Peninsula. Most of those were used to the late Persian Emperors behind their sumptuous palaces and intimidating pomp that was the only way to assert respect for the state and its order. 'Umar, in his humble attire and absence of outward signs of authority, such as body guards and motorcade, etc. would not have commanded respect to those indiscriminating masses who would have judged him based on his shabby appearance as a poor Arab man from the desert.

Furthermore, geography is an important factor leading to decentralization. Table 2 depicts the dynamic change in the distance between 'Umar's capital of Medina and the periphery of his caliphate around $646 \mathrm{CE}$. The periphery of the caliphate when 'Umar took over can be represented by the area of Basra in southern Iraq. At the end of 'Umar's reign the caliphate expanded to the area v of Mashhad in Iran. If 'Umar or his envoy wanted to visit the periphery of his caliphate early on it would have taken him almost one month on camel back, the most efficient mode of transportation available at the time, while at the end of his reign, 'Umar would have needed two and a half months to reach the new periphery. Then, at the time of the 'Abbāsid caliphate, it would have taken a whopping six months for the caliph to travel from his capital in Baghdad to visit the periphery of his caliphate in the area of today's Rabat.

Table 2 shows distances and travel times from 'Umar's capital in Medina to the periphery of his caliphate (dominion) at the beginning and then the end of 'Umar's rule. The last line in the table 2 shows the estimated travel time from the new 'Abbāsid capital of Baghdad to the periphery has increased to 6 months at the time of the 'Abbāsids.

\begin{tabular}{|l|l|l|l|}
\hline Capital & Periphery & Distance $^{57}$ & Travel by camel $^{58}$ \\
\hline Medina & Basra area (Iraq) & 766 miles & One month (32 days) \\
\hline Medina & Mashhad (Iran) & 1867 miles & Two and a half months (78 days) \\
\hline Baghdad & Rabat area (Morocco) & 4379 miles & Six months (182 days) \\
\hline
\end{tabular}


No wonder then that Morocco and western north African areas became independent states after $750 \mathrm{CE}$ and remained that way until our days. The increasing distance correlates with the absence of a centralized government in the larger 'Abbāsid caliphate and all its successors afterwards.

Therefore, an image of the caliphate as vast as the 'Abbāsid caliphate governed by a character akin to 'Umar's in his idealistic manners and style, is an ahistorical and an unrealistic one that never existed as such. But did Muslims really have only one caliphate at a time throughout the bulk of their history?

\section{MORE THAN ONE CALIPHATE EXISTED SIMULTANEOUSLY}

History instructs us that over the years that followed the advent of the Caliphate institution in $632 \mathrm{CE}$, Muslims have had periods where two, or more caliphates existed simultaneously for several years. The late Egyptian historian Hussain Mones devotes the first few pages ${ }^{59}$ of his Atlas al-tarikh al-islami (Atlas of Islamic History) to a graphical depiction of various caliphate systems and dominions spanning the almost 1400 years of Islamic history.

Looking at a snapshot of the various caliphates and dominions we can easily note the existence of more than one simultaneous caliphate at the same time. We can start as early as $680 \mathrm{CE}$, where two caliphates were fighting, one was the Umayyads with their capital in Damascus against their rebel rival Abd Allah Ibn al-Zubayr ${ }^{60}$ whose capital was in Mecca. Ibn al-Zubayr was finally defeated and killed by the Umayyad caliph Abd al-Malik ${ }^{61}$ Another example is the simultaneous coexistence of three caliphates over 161 years: the Fatimīd caliphate (909-1171 CE) ${ }^{62}$ in Egypt, Syria, the Arabian Peninsula and North Africa; The Umayyad II caliphate(929-1030 CE) ${ }^{46}$ in Spain; and 
the 'Abbāsid caliphate (750-1258 CE) which had reduced to Iraq, Persia (Fars) and the land of today's Afghanistan. Furthermore, Muslims had up to six Caliphs coexisting in the period between $934 \mathrm{CE}$ and $955 \mathrm{CE}$, as depicted in the table 3 and graph 2 below. There were periods when there was no caliphate at all. For example, between $1924 \mathrm{CE}$ and $1956 \mathrm{CE}$ there was no ruler claiming to be a caliph after the abolishment of the Ottoman caliphate in 1924 CE. In 1956 CE, with the independence of Morocco, the Moroccan caliph became independent again, and the title Amir al-Mu'minin continues to be used in Morocco today to address the Moroccan king. Muslim societies continued to exist and implement Islamic laws by their rulers regardless of the title taken by the authority or the governing system chosen. In fact the contemporary Moroccan king fulfills all the criteria that most classical scholars, such as al-Mawardi had stipulated, including the Qurayshi ancestry as a requirement for the caliph. ${ }^{63}$

The following table 3 and chart 2 one can find more examples of simultaneously coexisting caliphates spanning over 13 centuries after the death of the Prophet.

Table 3: Caliphates 632-2015 $\mathrm{CE}^{64}$ Please note that some territories are mentioned under more than one caliphate in the table, such as Egypt that was under both the 'Abbāsid caliphate and the Fatimīd caliphate. The fact is Egypt in this example started under the 'Abbāsid caliphate before moving to become part of the Fatimīd caliphate and so on.

\begin{tabular}{|c|c|c|c|c|}
\hline Caliphate & Beg. & End & Duration & Location \\
\hline $\begin{array}{l}\text { Rightly guided: } \\
\text { Abu Bakr, 'Umar, } \\
\text { Usman, Ali }\end{array}$ & $632 \mathrm{CE}$ & $660 \mathrm{CE}$ & $28 \mathrm{yrs}$ & $\begin{array}{l}\text { Arabia, Egypt, } \\
\text { Syria, Iraq, Iran }\end{array}$ \\
\hline $\begin{array}{l}\text { Umayyads I in } \\
\text { Damascus caliphate }\end{array}$ & $661 \mathrm{CE}$ & $750 \mathrm{CE}$ & $95 \mathrm{yrs}$ & $\begin{array}{l}\text { Arabia, Egypt, } \\
\text { Syria, Iraq, Iran, } \\
\text { North Africa, } \\
\text { Spain }\end{array}$ \\
\hline $\begin{array}{l}\text { Abdullah Ibn al- } \\
\text { Zubair caliphate }\end{array}$ & $680 \mathrm{CE}$ & $692 \mathrm{CE}$ & $12 \mathrm{yrs}$ & $\begin{array}{l}\text { Arabia, Egypt, and } \\
\text { Iraq }\end{array}$ \\
\hline 'Abbāsid caliphate & $750 \mathrm{CE}$ & $1258 \mathrm{CE}$ & 508 ys & $\begin{array}{l}\text { Arabia, Egypt, } \\
\text { Syria, Iraq, Iran, }\end{array}$ \\
\hline
\end{tabular}




\begin{tabular}{|c|c|c|c|c|}
\hline & & & & $\begin{array}{l}\text { North Africa, and } \\
\text { Sind }\end{array}$ \\
\hline $\begin{array}{l}\text { Banu Țabațaba } \\
\text { caliphate }^{65}\end{array}$ & $814 \mathrm{CE}$ & $955 \mathrm{CE}$ & $141 \mathrm{yrs}$ & Yemen \\
\hline $\begin{array}{l}\text { Tabaristan } \\
\text { caliphate }^{66}\end{array}$ & $864 \mathrm{CE}$ & $956 \mathrm{CE}$ & 92 yrs & Iran \\
\hline Fatimid caliphate ${ }^{62}$ & $909 \mathrm{CE}$ & $1171 \mathrm{CE}$ & $262 \mathrm{yrs}$ & $\begin{array}{l}\text { Arabia, Egypt, } \\
\text { Syria, Mid North } \\
\text { Africa }\end{array}$ \\
\hline $\begin{array}{l}\text { Spanish Umayyad } \\
\text { II caliphate } 46\end{array}$ & $929 \mathrm{CE}$ & $1030 \mathrm{CE}$ & $101 \mathrm{yrs}$ & Spain \\
\hline Zaydis I caliphate $^{67}$ & $943 \mathrm{CE}$ & $1018 \mathrm{CE}$ & $75 \mathrm{ys}$ & Yemen \\
\hline Almohad caliphate & $1150 \mathrm{CE}$ & $1269 \mathrm{CE}$ & $119 \mathrm{ys}$ & $\begin{array}{l}\text { Morocco, Algeria, } \\
\text { Tunis and Spain }\end{array}$ \\
\hline Hafsīd caliphate ${ }^{68}$ & $1230 \mathrm{CE}$ & $1574 \mathrm{CE}$ & 344 yrs & $\begin{array}{l}\text { Tunisia, and } \\
\text { Algeria }\end{array}$ \\
\hline $\begin{array}{l}\text { Marīiniīd } \\
\text { caliphate }^{69}\end{array}$ & $1269 \mathrm{CE}$ & $1465 \mathrm{CE}$ & $196 \mathrm{yrs}$ & $\begin{array}{l}\text { Morocco and } \\
\text { Algeria }\end{array}$ \\
\hline Sa'di caliphate $^{70}$ & $1510 \mathrm{CE}$ & $1658 \mathrm{CE}$ & 148 yrs & $\begin{array}{l}\text { Morocco, and } \\
\text { Algeria }\end{array}$ \\
\hline Mughal caliphate $^{71}$ & $1556 \mathrm{CE}$ & $1857 \mathrm{CE}$ & $301 \mathrm{yrs}$ & India \\
\hline $\begin{array}{l}\text { Zaydis II } \\
\text { caliphate }^{72}\end{array}$ & $1636 \mathrm{CE}$ & $1805 \mathrm{CE}$ & $169 \mathrm{yrs}$ & Yemen \\
\hline $\begin{array}{l}\text { 'Alawid I } \\
\text { caliphate }^{73}\end{array}$ & $1658 \mathrm{CE}$ & $1912 \mathrm{CE}$ & $254 \mathrm{yrs}$ & $\begin{array}{l}\text { Morocco, and } \\
\text { Algeria }\end{array}$ \\
\hline Ottoman caliphate ${ }^{74}$ & $1770 \mathrm{CE}$ & $1924 \mathrm{CE}$ & $154 \mathrm{yrs}$ & $\begin{array}{l}\text { West Arabia, } \\
\text { Syria, Egypt, } \\
\text { Libya, Tunisia, } \\
\text { and Algeria }\end{array}$ \\
\hline Sokoto caliphate $^{75}$ & $1804 \mathrm{CE}$ & $1903 \mathrm{CE}$ & 99 yrs & $\begin{array}{l}\text { North Nigeria and } \\
\text { surrounding area }\end{array}$ \\
\hline $\begin{array}{l}\text { Zaydis III } \\
\text { caliphate }^{76}\end{array}$ & $1840 \mathrm{CE}$ & $1871 \mathrm{CE}$ & $31 \mathrm{yrs}$ & Yemen \\
\hline $\begin{array}{l}\text { Zaydis IV } \\
\text { caliphate }^{77}\end{array}$ & $1920 \mathrm{CE}$ & $1962 \mathrm{CE}$ & $42 \mathrm{yrs}$ & Yemen \\
\hline $\begin{array}{l}\text { 'Alawid II } \\
\text { caliphate }\end{array}$ & $1956 \mathrm{CE}$ & $2015 \mathrm{CE}$ & 59 yrs & Morocco \\
\hline
\end{tabular}




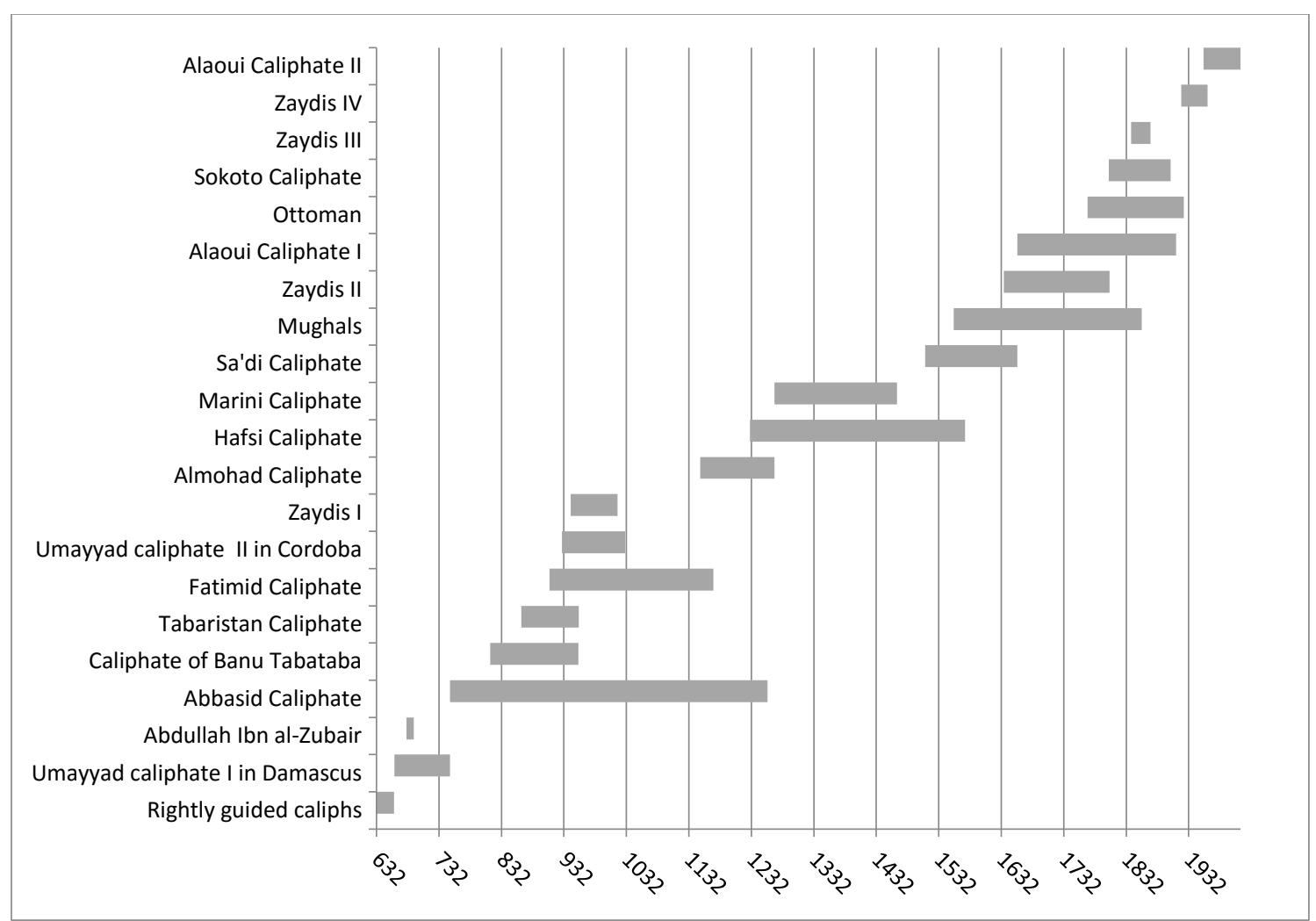

Chart 2 Caliphates 632-2015 CE

Furthermore, one cannot overlook the changing and evolving meaning of the word caliph and his caliphate. It appears that the concept of the caliphate that grew naturally from the social and political needs of the Muslim community in Medina in the early days of Islam continued to evolve in its various forms depending on the exigencies of geography and growing sophistication of the community. This is obvious when one compares two different periods, the time of the Umayyad I caliphate in Damascus (661750 CE) with its hostile rival caliphate of Abd Allah b. al-Zubayr in Mecca (680-692 CE). Neither Abd Allah b. al-Zubayr in Mecca nor his Umayyad rival Abd al-Malik b. Marwan, in Damascus were willing to accept the idea of two caliphs existing simultaneously. The caliphate of Abd Allah b. al-Zubayr ended after 12 years by his demise. This rejection of more than one caliphate continued through the first two hundred years or so after the death of the Prophet continued through the early period of 
the 'Abbāsid caliphate. When Abd al-Rahmān I (Umayyad II) escaped the massacre in Damascus to rule Muslim Spain, he did not declare himself a caliph. In 929 CE, one of his descendants Abd al-Rahman III, ${ }^{79}$ declared an Umayyad caliphate in Spain. What was unacceptable in the seventh century at the time of lbn al-Zubayr and Abd al-Malik, became grudgingly tolerated in the tenth century and later as depicted in table 3 and chart 2 . One way to help understand the evolutionary changes the caliphate went through in adapting to a new environment is to classify the format of the caliphate into three types:

- Type I, a centralized caliphate with a single caliphate system (632-750 CE):

This basically consists of the four rightly guided caliphs and the Umayyad caliphate in the first 118 years after the death of the Propet. More than one caliphate was unacceptable.

- Type II, decentralized caliphate, more than one caliphate is grudgingly tolerated. ('Abbāsid caliphate, 750-1258 CE and the Ottoman caliphate, 1774-1924 CE):

Many independent dominions within the same caliphate paid tribute to the caliph, though remaining independent, and even passing on the post to their children with the acquiescence of the caliph as we saw above with the Aghlabīds in north Africa. Other caliphate systems could exist simultaneously such as the Fāțimiīds caliphate between 909-1171 CE that coexisted with the 'Abbāsid caliphate.

- Type III, regional caliphate systems, $814 \mathrm{CE}$-current times:

Their type of governance was centralized in a smaller area. They are less inclined to make claims over other territories or dominions. This includes the many caliphates in north west Africa, down to today's Morocco caliphate of the 'Alawid family. 
Table 4 and chart 3 below, depict most of the caliphate systems according to the above classification, with the total number of caliphate systems in the column on the right column.

Table 4: Three different types of caliphate systems. Additional type III contemporary caliphates are listed in the notes column.

\begin{tabular}{|c|c|c|c|c|}
\hline Year & $\begin{array}{l}\text { Type } 1 \\
\text { Caliphate } \\
\end{array}$ & $\begin{array}{l}\text { Type } 2 \\
\text { Caliphates }\end{array}$ & $\begin{array}{l}\text { Type } 3 \\
\text { Caliphate } \\
\end{array}$ & $\begin{array}{l}\text { Total } \\
\text { Caliphates } \\
\end{array}$ \\
\hline $700 \mathrm{CE}$ & $\begin{array}{l}\text { Umayyads I in } \\
\text { Damascus } \\
(661-750 \mathrm{CE})\end{array}$ & & & 1 \\
\hline $800 \mathrm{CE}$ & & $\begin{array}{l}\text { 'Abbāsids (750- } \\
1258 \mathrm{CE})\end{array}$ & & 1 \\
\hline $900 \mathrm{CE}$ & & 'Abbāsids & & 1 \\
\hline $\begin{array}{l}1000 \\
\mathrm{CE}\end{array}$ & & 'Abbāsids & $\begin{array}{l}\text { 3: Umayyads II } \\
\text { in Cordoba, } \\
\text { Fatimīds in } \\
\text { Egypt, \& Zaydis } \\
\text { in Yemen }\end{array}$ & 4 \\
\hline $\begin{array}{l}1100 \\
\text { CE }\end{array}$ & & 'Abbāsids & $\begin{array}{l}\text { 1: Fatimīds in } \\
\text { Egypt }\end{array}$ & 2 \\
\hline $\begin{array}{l}1200 \\
\mathrm{CE}\end{array}$ & & 'Abbāsids & $\begin{array}{l}\text { 1: Almohads in } \\
\text { Spain }\end{array}$ & 2 \\
\hline $\begin{array}{l}1300 \\
\mathrm{CE}\end{array}$ & & & $\begin{array}{l}\text { 2: Hafsīds \& } \\
\text { Meriīnīds in N } \\
\text { Africa }\end{array}$ & 2 \\
\hline $\begin{array}{l}1400 \\
C E\end{array}$ & & & $\begin{array}{l}\text { 2: Hafsīds \& } \\
\text { Meriīnīds in N } \\
\text { Africa }\end{array}$ & 2 \\
\hline $\begin{array}{l}1500 \\
\mathrm{CE}\end{array}$ & & & $\begin{array}{l}\text { 1: Hafsīds in } \mathrm{N} \\
\text { Africa }\end{array}$ & 1 \\
\hline $\begin{array}{l}1600 \\
\mathrm{CE}\end{array}$ & & & $\begin{array}{l}\text { 2: Sa'dīs in N. } \\
\text { Africa, Mughals } \\
\text { in India }\end{array}$ & 2 \\
\hline $\begin{array}{l}1700 \\
\mathrm{CE}\end{array}$ & & & $\begin{array}{l}\text { 3: 'Alawids in } \\
\text { Morocco, Zaydis } \\
\text { in Yemen, } \\
\text { Mughals in India }\end{array}$ & 3 \\
\hline $\begin{array}{l}1800 \\
\mathrm{CE}\end{array}$ & & $\begin{array}{l}\text { Ottoman } \\
\text { (declared a } \\
\text { caliphate 1774) }\end{array}$ & $\begin{array}{l}\text { 1: 'Alawids in } \\
\text { Morocco, } \\
\text { Mughals in India }\end{array}$ & 3 \\
\hline $\begin{array}{l}1900 \\
\mathrm{CE}\end{array}$ & & $\begin{array}{l}\text { Ottoman (ended } \\
\text { 1924); }\end{array}$ & $\begin{array}{l}\text { 2: 'Alawids in } \\
\text { Morocco }\end{array}$ & 3 \\
\hline
\end{tabular}




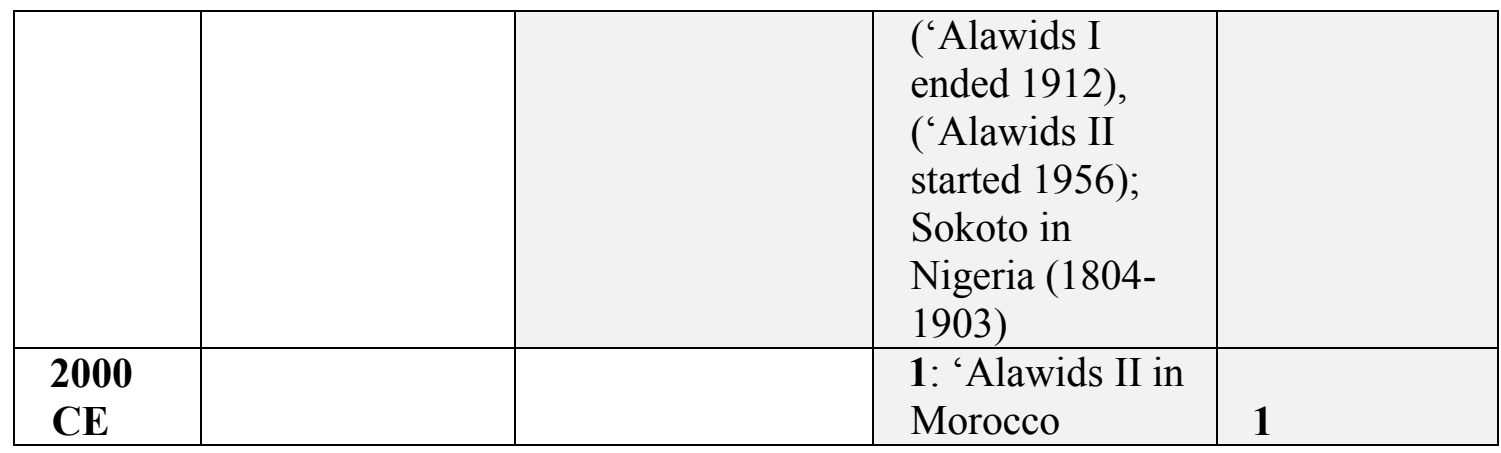

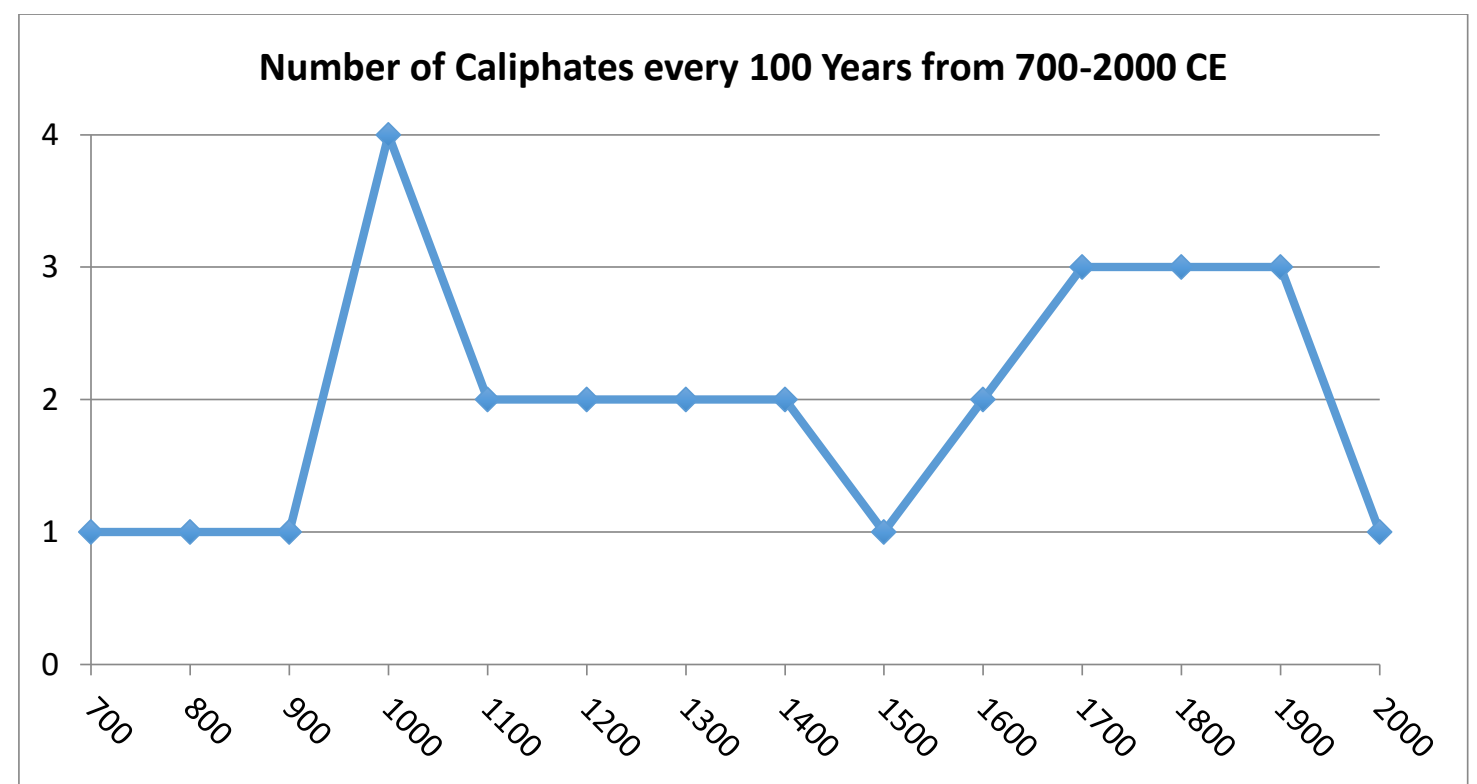

Chart 3 A snapshot depicting the number of caliphate systems every 100 years of the Common Era.

Most of the 1400 years of Islamic history witnessed multiple independent dominions with more than one caliphate system at the same time. In the last few paragraphs we witnessed the evolution of the concept of the caliphate system from its inception until today. We were able to see how it evolved progressively from a type 1 centralized system of governance that would not accept rival caliphs into a vast type 2 decentralized dominion with many de facto independent states pledging allegiance to their caliph symbolically. In type II there was grudging acceptance for the idea of many caliphs, each ruling a separate territory. And finally we witnessed the emergence of a 
type III caliphate system where the caliph rules a relatively limited land with no universal claims, like what has existed in Morocco until our day. The Moroccan king is called by the title reserved only for caliphs: "the commander of the faithful." Based on the review above, the meaningful use of the term caliph should always refer to the relevant historic era.

Having shed some light on two of our three exploited misconceptions about the caliphate, we will now explore whether the caliphate is mandated by the religion.

\section{DOES THE RELIGION OF ISLAM DICTATE A CALIPHATE?}

Does the religion of Islam dictate a blue print for governance in the political life of Majority-Muslim societies, a system called the caliphate as some claim?

The religion of Islam is based on the Qur'an that all Muslims believe it to be God's verbatim word. The second most important source of religious guidance to Muslims is the tradition established by Prophet Muhammad whose task was not only to deliver God's word, the Qur'an, but to also set up an example for its application in daily life. In order to examine the relationship of the idea of caliph with the core of Islamic teachings we will search the Qur'an, and the traditions of the Prophet for the original Islamic concepts of "governance" and "caliphate."

We will then trace the birth and evolution of the caliphate immediately after the death of the Prophet when Abū Bakr became the first caliph in order to assess the relationship between the concept of the caliphate and the religion of Islam. In this section, I will argue that the caliphate was a method of governance compatible with Islamic teachings and stemming out from the local culture in Arabia at the time. It 
allowed the implementation of Islamic values and continued to evolve hand in hand with the changing cultural conditions. It is only one of many possible cultural political vehicles to express Islamic values in society. The core values of Islam are immortalized in the Qur'an, but the modality of their expression and interpretation varies based on the culture and time of the interpreter.

\section{A. There is no caliphate in the Qur'an}

Let's look up in the Qur'an the five major word roots connected to governance: caliph(ate), king, state, govern(ment) and command.

\section{Caliph(ate):}

The word caliph (khalifa) is mentioned twice in the Qur'an in its singular form. ${ }^{80} \mathrm{In}$ one verse God talks about making Adam as a khalifa (vicegerent) on earth. In the second verse God reminds David that he had made him a khalifa and admonishes him to judge his people in fairness. In this verse David's qualification as khalifa does not seem to be different from that of Adam or Adam's offspring -all of humanity. A modern writer comments on those two verses by saying the word khalifa applies to human kind in general as in the example of Adam, it also applies to one who passes judgments frequently as in the example of David. ${ }^{81}$ It is therefore clear that khilafa in the Qur'an connotes a mission that applies to the entire human kind as much as it applies to David with no relation to systems of governance. The system of governance called khilafa (caliphate) was developed by the Prophet's companions after the Prophet's death. This not withstanding, there is no special mention of Muhammad or his followers as being a khalifa (caliph) in the Qur'an. Moreover, when the word khalifa is mentioned in its plural form in the Qur'an it is explicitly describing those who call on God as the 
inheritors-vicegerents of earth (khulafa': plural of khalifa-caliph). It does not imply any political post. ${ }^{82}$

\section{King:}

The word mulk (kingship) is often mentioned in reference to God in the Qur'an; it also mentioned in a neutral way when referring to David and Solomon. ${ }^{83}$ The Qur'an evokes kingship in a negative light on two occasions. ${ }^{84}$ Kingship is never associated with Muhammad or the Muslim community in the Qur'an.

\section{State:}

The Arabic word for state is dawla, but using dawla to connote state is probably a later development in the eighth century. Its root is $d w l$ which means "to rotate, turn, change, alternate, or succeed one another." 85 The word dawla is mentioned only once in the Qur'an in verse 59:7. It aims at the prevention of the exclusive recycling of wealth that could go round around among the rich. In that verse God prescribes eight categories of people who should receive a share. And even if one is to accept the ahistorical retrospective projection of the meaning or the word dawla and takes it to mean state for the sake of argument, the affair of state would clearly be something that goes round and round and cannot be a dictatorship. But again this ahistorical usage is still a forgery.

Therefore, there is no mention of "state" as a method of governance in the Qur'an.

\section{$\operatorname{Govern}(m e n t):$}

The Arabic word for the verb "govern" is hakama, and the word for government is hukümah. Both words stem out of the root word hukm. At the time of the Qur'anic revelation $h u k m$ meant the "function of adjudicating disputes by way of arbitration. It also meant wisdom." ${ }^{86}$ Bernard Lewis explains that it was only later during the Middle 
Ages that the root of hukm and its derivatives were extended to include political as well as judiciary authority. ${ }^{87}$ Projecting a later meaning of a word and reading it in an older text is a major source of confusion and error. Let's look at some of the many verses in the Qur'an that use the root hukm: in verse 5:42, the Prophet is given the choice when asked to judge $(h u k m)$ or not to judge, but if he chooses to judge, he should do so in. ${ }^{88}$ Similarly, in verse 4:58, the Qur'an admonishes the whole Muslim community to judge fairly when asked. ${ }^{89}$ The word hukm in the Qur'an therefore, cannot be government in the political sense. In a third verse, 12:22, Joseph is described as someone who was given the faculty of fair judgment when he attained maturity. ${ }^{90}$ It is obvious therefore that hukm according to the Qur'an could not mean governing, since Joseph was not a king. Therefore, the claim that the Qur'an enunciates a system of government as some Muslims do is unsubstantiated because they apply a later meaning of the word hukm retroactively to a previous era, ignoring how the word is used in other Qur'anic verses. Some Muslims refer to verses 5:44 and 5:45 91 to support their claim that the Qur'an has a specific system of governance. Those verses refer to some Jews who do not judge according to their scripture as deniers of truth and transgressors. Moreover, verse 5:4792 calls Christians who do not judge according to the guidance of the Gospel iniquitous.

\section{Command (amr):}

The word $a m r$, is used in the Qur'an and early Islamic texts in the sense of “authority" and "command." The person who holds authority is called amir $^{93}$, hence 'Umar, the second caliph (sovereign) used the title amir al-Mu'minin (the commander of the believers) as mentioned earlier. The Qur'an does not specify any method of amr. Nevertheless, the Qur'an emphasizes the importance of mutual consultation in 
conducting affairs. Verse $42: 38^{94}$ recommends mutual consultation: God promises good rewards to those who respond to God, establish prayers and conduct their affairs in mutual consultation. Furthermore, verse 3:15995 addresses the Prophet himself in the aftermath of the Muslim community's defeat in the battle of Uhud. In planning for the battle of Uhud, according to classical Muslim commentators, the Prophet instructed a division of his fighters to stay at mount Uhud and to never leave in order to protect the rear position of the rest of the Muslim fighters. But when that division thought the battle was won, they abandoned their post prematurely. This led to a successful attack by the enemy at the Muslim rear position resulting in defeat of the Muslims. In verse 3:159 God instructs his Prophet to be kind to his companions, forgive them, ask God to forgive them, and consult them in amr (the organization of their worldly affairs). Therefore, although the Qur'an emphasizes the importance of mutual consultation, there is no description of a specific method of governance beyond the all-inclusive principle of mutual consultation.

Finally, it should be clear by now that the word khalifa was born as a political term with the establishment of the first government in the history of Islam under the leadership of Abū Bakr, which was a very simple one. But what the caliphate and a caliph meant continued to evolve constantly to reflect changes in Muslim societies. According to the Muslim tradition, the first four (rightly-guided-caliphs) embodied simplicity, personal piety, justice, and mutual consultation. However, with the Umayyad dynasty, a caliph demonstrated tyranny, luxury, intrigue, and instances of injustice, a state of affairs that dominated until modernity. Furthermore, when the 'Abbāsids took over after a hundred years of the Umayyad rule, the caliphate became a vast dominion, 
most of which independent, a situation that will also extend to modernity. Therefore, the word caliphate has evolved with Muslim societies over the centuries to mean different things at different times, both structurally and morally. It is the lack of awareness of the historical evolution of terms such as the caliphate and government ( hukm) that allows confusion and exploitation.

We shall proceed to probe the second authoritative religious source in Islam after the Qur'an, the Prophet himself, to determine whether he considered himself a caliph or recommended a caliphate.

\section{B. The Prophet never viewed himself more than a messenger of God and community leader}

A reading of the biography of the Prophet in its historical context of seventh century is of paramount importance to ensure our correct understanding of the life and conduct of the Prophet.

A good place to start is to review the charter of Medina, commonly and only recently referred to as the "constitution of Medina." This is a written document that asserts the freedom of each tribe and religious group in Medina to live freely according to their customs and religion. It grants each group protection while each party commits to participate in defending the society and in return gets to share in war booty. Here we need to be careful not to make generalizations stemming out of our modern understanding of the word constitution. ${ }^{96}$ The word constitution in Arabic usage is dustūr. It comes from Persian and was first used in the Muslim world to refer to the constitution of Tunisia in $1861 \mathrm{CE} .{ }^{97}$ Neither the word constitution nor the notion of a constitutional government was known or possible in Arabia at the time of the Prophet. 
Certainly one can assert that the Prophet subscribed to the principle of mutually agreeing on a binding written document in society, and one can read in it stark compatibility and even inclination to modern constitutional rule. However, we should not lose sight of the fact that neither the Qur'an, nor the Prophet's disciples viewed him as a governor or a king, as we shall see below.

Therefore, the labeling of the pact of Medina as the constitution of Medina could be confusing and could lead one to assume the existence of a constitutional government in the modern sense in Medina in the seventh century. The pact of Medina is comparable to a pact done at the time of the Prophet's youth in Mecca (pact of $a l-f u d \bar{u} l) .{ }^{98}$ The pact of Medina did not refer to the Qur'an, and both pacts preserved the independent nature of each tribe without forging them into one nation or interfering with each tribe's "customary preferences." The pact of Medina established an alliance between Muslims and some of the Jewish tribes where each keeps their religion without interference. Both groups had responsibility for expenses as well as a share of war booty. ${ }^{99}$ Therefore, while this was in the same spirit that animated constitutional democratic states, the pact of Medina was not a constitution, and the Prophet was not a head of state.

The pact starts by saying: "In the name of God the most compassionate the most merciful. This is a writ from Muhammad the Prophet among the believers, the Muslims from Quraysh and those from Yathrib [Medina] and whoever joined them and struggled with them." ${ }^{100}$ This also shows that the Prophet did not see himself neither wanted anyone to view him as a head of state or a prince; he saw himself only as the "Prophet" of God. Hichem Djäit, a contemporary Tunisian historian points to the significant omission of any allusion to this pact in the Qur'an possibly "because it is a political act, 
not a religious one," ${ }^{, 101}$ further supporting the fact that the Qur'an does not impose any blue print of a political system of governance beyond the general principles of justice and mutual consultation.

Furthermore, the Prophet's objective, "essential vocation, and the core of his mission was not to establish an Arab state nor to unify the Arabs, but to call them to the truth and save them from God's chastisement..." ${ }^{102}$ Practically speaking however, the Prophet was establishing a foundation that would make building a unified state for the first time in the history of Arabia possible. The Prophet never succumbed to the seduction of political power, he never wanted to invest in politics more than what was necessary to deliver the divine message. One of the early biographers of the Prophet Ibn Hishām (d circa $828 \mathrm{CE}$ ) recounts a story that illustrates the Prophet's disinterest in politics per se. We are told that 'Utba b. Rabi'a approached the Prophet in Mecca at the beginning of the call to Islam and said: “...if you are seeking wealth with what you brought [call to Islam] we would collect from our money so you become the richest, if you are seeking prominence we can make you our leader with no decision made without your consent, and if you are seeking lordship we could make you our king...."103 The Prophet rejected all of that. ${ }^{104}$

If one considers coercion by authority as the most basic principle of any governing body or state then on this basis alone, one can affirm that the Prophet never acted as a head of state. As we discussed above the Qur'an clearly gives the Prophet the choice of arbitrating and judging in disputes that reach him. The Prophet neither considered nor acquired a regular full-time army or police force to enforce his judgments on people that sought him out. This is far removed from the basic rules of state where all 
arbitrations and disputes are regulated by government, even in those cases delegated to local authorities. For "the implementation of religious law and documents, such as the șahiffa [pact of Medina] were left for the group of believers, as a whole, to implement, not a definite body or person." ${ }^{105}$ Djäit tells us:

In year 9 [after the migration of the Prophet from Mecca to Medina] many Medinans were not willing to join the [military] expedition of Tabuk in the extreme north in spite of injunctions of the Qur'an (al-Tawba [chapter 9]) and the vigor of [Qur'anic] reprobation, meaning God could only threaten absentees from the expedition by Hell fire in the future after-life ${ }^{106}$

Therefore, even in war, where all societies consider coercion legitimate, there was no physical coercion beyond moral admonition and the Qur'anic threats of punishment in the hereafter for disobeying the Prophet.

A more in-depth look at the structure of what some like to call the Prophet's state in Medina, clearly demonstrates the lack of any significant administrative structure. Sa'id al-'Ashmawi, the late Egyptian supreme court judge (d 2013 CE) informs us, there were ...no managerial bodies at the time of the Prophet, no bureaus, police, or administrative bodies. Neither did the Prophet, nor did his delegate oversee agriculture, commerce, provisions, irrigation or similar aspects of the community. The Prophet did not mint money, nor establish a monetary system, or a treasury house. ${ }^{107}$

A government with no bureaus, police, or overseer is hard to be conceived as a government by anyone. Furthermore, no entity can merit the designation as a government without imposing taxes, which means a government will coarse its citizens 
to pay taxes, for taxes are never voluntary, by definition. Al-'Ashmawi tells us about taxes, or lack thereof under the Prophet's leadership:

...There were no land taxes, nor duty taxes. Taxes were imposed only later after the establishment of the Muslim state at the time of the rightly guided caliphs, step-by-step in adaptation from the systems of Persia, Byzantium and Egypt. ${ }^{108}$

So taxes emerged later on accompanying the emergence of the state after the Prophet's death. The Prophet received religious alms and other payments in his capacity as the Prophet, not a head of state. For, Zakat was voluntary, indicating charity; șadka (later called zakat) used to be paid to the Prophet in his capacity as a Prophet not a governor, with the Prophet praying for them in return, 9:103. ${ }^{109} \mathrm{Fay}$ ' (war booty acquired without fighting) went specifically to the Prophet, by reason of being a messenger of God, not a governor, for the [Qur'anic] verse that regulates it links the Prophet to God, 59:7. ${ }^{110}$ The regulation of war-booty...was comparable to that of fay' and sadaka, includes the Prophet by virtue of Prophecy, not dominion...so the Prophet did not have a government, the way we understand it today... what he got as sadaka, fay', or booty was due to him as a Prophet as specified in the Qur'an, not as a governor, king, or prince. ${ }^{11}$

For even though those religiously mandated payments were due to the Prophet who then distributed them as specified in the Qur'an while some far regions distributed their payments locally in lieu of sending them to the Prophet. ${ }^{112}$ There is a story about a man who initially declined to pay zakat to the Prophet, the Prophet left him alone. ${ }^{113}$ The religious and voluntary nature of those payments cannot be overemphasized. Reading 
the biography of the Prophet carefully negates any misleading semblance to a tax imposed by the authority of law until the death of the Prophet. Djäit succinctly describes the Prophet's career from a historian point of view: “...the Prophet left a religion he modeled, a sacred book - the Qur'an, where the basic beliefs were laid out, a strict monotheism, a ritual and moral code...he formed a pacified territory attached to the new religion, and the embryo of a state that was to develop." 114 Therefore, although the Prophet ended up creating an "embryo of a state", there is no evidence that he ever visualized himself as a head of state. Furthermore, there is no evidence that he aspired to building an Empire or to extending his reach beyond the Arabian Peninsula. ${ }^{115}$ This is something Abū Bakr, his first successor and head of the new caliphate will do, not the Prophet. ${ }^{116}$ For it is with Abū Bakr that the state that came to be known as the caliphate is born.

We have seen in the paragraphs above that the Qur'an neither considered the Prophet a head of state nor did the Prophet view himself as such. This is demonstrated in the way he is described in the pact of Medina. There was no coercion, even at times of war when there is a need to rally enough troops to defend the burgeoning Muslim community. The only coercion, if any, was the threat of chastisement in the hereafter by the Qur'an; there was no material exercise of an authority of a state. This fully negates any state nature of the leadership of the Prophet who had no police force, no bodyguards, and no permanent army. The Prophet had no office and no subordinates that any head of a state would have. What resembled a tax at first blush turns out to be a voluntary religious charity to the needy without coercion, and not always collected by the Prophet himself. Some remote tribes were allowed to disburse it locally as specified in the 
Qur'an. And finally, the interest in empire building is absent in the Prophet's vision. Nevertheless, a state that was called the caliphate would have been impossible, had it not been for the unification of most of Arabia under the effective and charismatic persona of the Prophet and the unification of all tribes of Arabia via the new monotheistic religion. It was up to Abū Bakr to take on state and Empire building that the times mandated. The young energetic Muslim community was well equipped to march out to the world under the leadership of the first caliph and his successors as we shall see shortly. In the next few paragraphs we shall explore how the caliphate merged after the death of the Prophet with the first caliph Abū Bakr.

\section{The political institution of the Caliphate emerged after the death of the Prophet with Abū Bakr's reign}

The Prophecy came to an end with the death of Muhammad but his role as a leader of the Muslim community had to be assumed by his followers. Had the running of community affairs been a religious matter, the Qur'an, or the Prophet would have given some guidance on the identification of the next leader. When the Prophet became ill, he asked Abū Bakr to lead the prayers in his stead with no hint at who should become the community leader afterwards. ${ }^{117}$ After the Prophet's death, no one knew who should become the leader. Therefore, the Prophet's choice of Abū Bakr to lead the prayers had no direct bearing on who the leader should be. This state of affairs lends a solid argument favoring separation between religious and political leadership as practiced by the Prophet and his companions. ${ }^{118}$ This becomes clearer when we read some of the seminal historic texts describing the process through which Abū Bakr was selected to be the first leader after the death of the Prophet. It was an unpredictable and emotionally charged process. 
Two early classical historians allow us a glimpse at the events that took place in Medina, in the wake of the Prophet's death. They are Ibn Hisham, an early biographer of the Prophet (d $828 \mathrm{CE})$ and al-Tabari (d $932 \mathrm{CE})$.

The Supporters (native citizens of Medina) reacted to the sudden void in leadership after the Prophet's death by pledging to one of their own as the leader. ${ }^{119}$ They were acting as any tribe would act when it loses its leader in Arabia at the time. For after all, they are the natives of Medina who invited the Prophet to migrate with his Meccan followers to become their leader. However, the Migrant community leaders such as Abū Bakr and 'Umar felt that since the Prophet was from their tribe, the leadership should go to the Prophet kinsfolk in the Immigrant community. When Abū Bakr and 'Umar arrived in the sakifa, 'Umar thought to himself, "Supporters wanted to downplay the Immigrants' prominence and usurp the leadership." ${ }^{20}$ So the Immigrants were reacting from within the tribal norms of the time as well. There does not seem to be anything religious about it. In the meeting, Abū Bakr said: "O Supporters, you are worthy of every virtue you mentioned but Arabs have not known leadership to belong anywhere outside this quarter of Quraysh for they are the most honorable of all Arabs in locale and lineage." ${ }^{121}$ Abū Bakr was affirming the non-religious basis on which leadership of the Muslim community was to be chosen. His argument was a pragmatic one, taking into consideration that the tribes away from Medina would not accept any leadership other than that of the tribe of the Prophet, the tribe of Quraysh. The argument seemed very convincing to the extent that one of the Supporters tried to compromise without fully giving up by saying: "If the Immigrants insist on the candidacy of Abū Bakr, then let's choose two rulers, one from each side." ${ }^{122}$ A suggestion that adds a pragmatic component 
to tribal norms. However, 'Umar retorted back, "this is impossible; two swords can never combine in one sheath. Arabs will not agree to give you-Supporters the leadership while their Prophet has come from a different locale. However, Arabs will agree to grant leadership to those in whom Prophethood took place. We will have a strong argument against those Arabs who refuse to pledge to us-Immigrants. And no one will be able to successfully dispute with us [our claim to] Muhammad's sovereignty and leadership, since we are his heirs and clan." 123 'Umar's argument again combining tribal norms with pragmatism to refute the case for compromise, there can only be one leader, and that leader has to be an Immigrant from the Prophet's tribe. Abū 'Ūbayda, an Immigrant adds an emotional appeal to the arguments of Abū Bakr and 'Umar, he says: "O Supporters, you have been the first to aid the Prophet, do not be the first to renege." 124 Again, religion is not invoked. Finally Abū Bakr advances a suggestion for an Immigrant candidate in stead of Sa'd, he says: "Here is 'Umar, and there is Abū 'Ūbayda [both are immigrants], pledge to either one you wish." ${ }^{.25}$ The resolve of the three Immigrant leaders is unshakable based on all the arguments they advanced. However, both 'Umar and Abū Ubayda said: "No, we will not take it on. You are the best of the Immigrants and the second of two in the cave ${ }^{126}$ and the one who succeeded him in prayer leading. Prayers are the most honored in our religion, no one should be ahead of you or take on the leadership before you. Stretch out your hand, so we could pledge allegiance to you.“"127 This added the unique prestige Abū Bakr had to the equation and built even a stronger case, for it was hard to compete with the credentials of Abū Bakr. It is noteworthy here that religion was used only as an ancillary credential, not as a main argument. This further illustrates the non-religious nature of the process of leadership. And so all 
[Immigrants and Supporters] pledged to Abū Bakr, except Sa'd b. 'Ubada ." Once the leaders made their decision about the leader, the next day the rest of the community, both supporters and immigrants, pledged allegiance to Abū Bakr with the exception of 'Ali, the cousin of the Prophet, an Immigrant, who did not pledge until much later. ${ }^{128}$ For 'Ali was the cousin of the Prophet and felt he was the most worthy of leadership. ${ }^{129}$

The unpredictability of the leader selection process that took place should be obvious. The process started with the initial selection of S'ad b. 'Ubada, the Supporters' leader then reversed by Abū Bakr and 'Umar. The winning arguments were pragmatic referring to the power structure in Arabia. Although the Supporters had power in Medina, the capital, their political authority had no sway outside of Medina, while the Immigrants had authority all over Arabia by virtue of belonging to the Prophet's Quraysh tribe with its pan Arabian prestige transcending its Meccan local since the preIslamic days.

The authority of the two most powerful sources of guidance to Muslims, the Qur'an and hadiths (sayings of the Prophet) were completely absent from the dispute about choosing the new leader. This further supports the argument that choosing a leader is a purely worldly matter, not a religious one. For example, no one quoted the alleged hadith that says all leaders have to be from Quraysh, which makes this hadith unlikely to be authentic, but a rather later addition. ${ }^{130}$ The Qur'an was evoked only to remind others of the honor Abū Bakr had, by referring to Qur'an's indirect allusion to him, but nothing more than that. This significant absence of the Qur'an and hadith in this dispute leads to the inevitable conclusion that there were no religious arguments to be made. The other significant point is that the choosing of Abū Bakr to lead prayers, a religious kind of 
leadership, had any direct bearing on his candidacy for the worldly leadership of the Muslim community. This argues for the separation between religious leadership and worldly leadership since the early days of Islam. Once more, the prevailing argument was a pragmatic one; it had everything to do with Arabia's customs that accept leadership on clan affiliation. As Thomas Arnold (d 1930 CE) puts it in his important work on the caliphate in $1923 \mathrm{CE}$ :

We have here an exemplification of the ancient Arab custom, in accordance with which, when the chief of a tribe died, his office passed to that member of the tribe who enjoyed the greatest influence, the leading members of the tribe selecting to fill the vacant place some one among themselves who was respected on account of age [sic], or influence, or for his good services $t$ the common weal; there was no complicated or formal method of election... and when the choice of a successor had been made, those present swore allegiance to him, one after another, clasping him by the hand." 131

Therefore, in the absence of any Qur'anic command or Prophetic guidance on how to choose a leader, it was natural for early Muslims to conduct their affairs in the best way they knew, through their culture and that was exactly how they chose their leaders and built their nascent state.

This is how the caliphate was born. It is not commanded by the Qur'an nor by the Prophet, although it was not incompatible with the Qur'an or the Prophetic teachings. Therefore, the caliphate is clearly not commanded by the religion; it is a culturally appropriate governing system developed by the companions of the Prophet after his death. 
Another elucidation of the worldly nature of the caliphate comes from what is known as the wars of apostasy. But before we go into the wars of apostasy that were led by $\mathrm{Abu}$ Bakr, it is helpful to revisit one of the issues that triggered those wars, namely the refusal of twelve Arab tribes to sends the alms they collect to Abū Bakr. As mentioned above, the Qur'an commands Muslims to pay alms called zakat, and an additional monetary contribution called șadaka. We have already related the Prophet allowing some remote tribes to disburse șadaḳa locally instead of sending it to him. We have also related the story of the man who refused to pay zakat with no worldly consequences. When that man decided to pay, the Prophet never accepted from him. Therefore, from a religious point of view, all religiously mandated payments were voluntary, not to be enforced by authority. Consequently, it is clear that the nature of the Prophet's leadership was not of a governmental type, since he did not impose sending collected alms to him.

But the caliphate was a totally different matter, for even though Abū Bakr was referred to as the caliph — the heir of the Prophet, the caliphate was acting like a bona fide government with religious symbols. There were twelve tribes in Arabia that refused to pay șadaḳa to Abū Bakr, claiming that the Qur'an says it is to be paid to the Prophet, and since the Prophet has died, there was no reason for them to pay it to Abu Bakr. This was a formidable challenge to the young caliphate. Only two of the twelve tribes had a man who claimed to be a new Prophet in contradiction to the Qur'an who qualifies Muhammad as the seal of Prophets. ${ }^{132}$ Therefore, from a religious point of view only two out of the twelve tribes were apostates. There was no precedent at the time of the Prophet fighting anyone who decided to disburse alms locally rather than send it to 
Medina. But what we are dealing with at the time of Abū Bakr's caliphate is the new logic of the state. A state will need to coerce all its citizens and enforce its laws; a state cannot survive merely on the good will of its citizens.

We hear of a conversation between 'Umar and Abū Bakr where the latter argues in favor of his decision to fight the tribes who refuse to send their alms to the new caliph Abū Bakr, trying to win 'Umar over. The mere fact that 'Umar initially opposed the idea of this war and Abū Bakr felt he had to marshal arguments to convince 'Umar proves the decision to fight was a political one that needed to be argued. Had it been a clear religious duty the two closest disciples of the Prophet, Abū Bakr and 'Umar, would not have needed to debate it.

'Umar told Abū Bakr: "how would you fight the people, while the Prophet of God (peace by upon him) said: 'I have been commanded to fight people until they say: there is no God but God, whoever says that he has secured himself and his wealth from me except for what is due, and his accountability to God.'” Abū Bakr said: "By God, I will fight those who have separated between zakat and prayer, for zakat is what is due over wealth, by God, had they withheld a camel's leash they used to give to the Prophet of God (peace be upon him) I would have fought them for withholding it," "Umar said: “by God, as soon as I saw that God has eased Abū Bakr's chest for fighting I knew it was the truth." Before I comment on the above narration, it important to note that the above mentioned hadith commanding Muslims to fight people until they proclaim that "there is no god but God" that 'Umar allegedly quoted is problematic for it contradicts verse 2:256 in the Qur'an where God proclaims freedom of religion, it also contradicts the practice of the Prophet who fought only those who were at war him or threatened 
peace. According to classical Muslim scholarship, any hadith that contradicts the Qur'an has to be rejected unless it could be validly reinterpreted in a way that would make it possible to reconcile with the Qur'an. ${ }^{133}$

In the above narration of the argument between Abū Bakr and 'Umar in the week of the "wars of apostasy", two things are noteworthy: First, Abu Bakr did not justify the fight by apostasy, since as mentioned above, 10 out of 12 tribes simply wanted to disburse alms locally and did not apostatize. Second, the justification for the war was not obvious to 'Umar. 'Umar had to see that Abū Bakr was confident of his decision to go to war before acquiescing to it. Had the justification for going to war been obvious at the outset on religious, such a close disciple to the Prophet like 'Umar would not have objected.

Works relating to governance in Muslim societies came late, and as Arnold reminds us the theory of the caliphate "...grew out of the facts, and represents the crystallization of opinion in the minds of the supporters of the Sunni Caliphate during the course of the first two centuries of the Muhammadan era. ${ }^{\text {"134 }}$ Therefore the Islamic works on governance have modeled themselves on the early caliphate and got modified according to changes in circumstances.

We have witnessed the birth of a new state at sakifat bani Sa'ida in $632 \mathrm{CE}$ after the death of the Prophet with the selection of Abū Bakr. There does not appear to be any credible evidence from what we have seen to support the claim that the caliphate is mandated by the religion of Islam. It was a natural new occurrence that had no clear reference in the Qur'an or the Sunna (the sayings and the deeds of the Prophet). One can argue however, that the leadership of the Prophet in uniting Arabia created the foundation 
for what later became the caliphate system in the hands of the Prophet's disciples immediately after his death. There was no direct Qur'anic or Prophetic instruction on how to do that. Therefore, the newly founded caliphate state was born as a civic state with religious symbolism. The wars of apostasy were merely asserting the central authority of the state. Nevertheless, we will need to address commonly used counterarguments the Qur'an and hadith mandate the establishment of the caliphate.

We have so far explored three exploited misconceptions about the caliphate and demonstrated that: the caliphate has not been one vast centralized dominion except for the duration of the last three of the four rightly guided caliphs and the Umayyad dynasty between 634-750 CE with no historic precedent of its recovery as such ever since. We then demonstrated that the assumption claiming there was no more than one caliphate at one period of time is ahistorical, applying only to short periods of Islamic history. And finally, we demonstrated that the caliphate is not mandated by the religion of Islam. We will now briefly consider some counterarguments from the Qur'an and the Sunna that could be advanced by advocates of the religious mandate for a caliphate.

\section{COUNTER ARGUMENTS ERRONEOUSLY CLAIMING ISLAM MANDATES A CALIPHATE}

All serious arguments and counterarguments in Islamic theology must reference at least one of Islam's founding texts which is primarily the Qur'an that Muslims believe is the verbatim word of God or the hadith of the Prophet. 


\section{A. The Qur'an}

Some might claim that the Qur'an has promised the caliphate. Verse 24:55 in the Qur'an is cited as an indication that God promises the caliphate to Muslims. The verse starts with "God has promised those of you who have attained to faith and do righteous deeds that, of a certainty, He will cause them to accede to power on earth..." The phrase "accede to power" is appropriately used in Muhammad Asad's translation to convey the meaning of the Arabic word layastakhlifannahum. A literal translation might have rendered layastakhlifannahum as "to make them caliphs," for the verb layastakhlifannahum is derivative from the same root verb as khalafa, which means to succeed - be in succession, and in this instance to be God's vicegerent in the same way that we see David as a vicegerent of God in verse 28:36 ${ }^{135}$ of the Qur'an as explained earlier in this essay. However, the term layastakhlifannahum is clarified by the rest of the sentence which reads: “...even as He [God] caused [some of] those who lived before them to accede to it..." So the word derived from the root verb khalafa is not talking about a specific system of governance that came later to be known as the caliphate, rather the verse says that God promises the Muslim community what he promised to those before them such as Adam and David. Asad comments on this verse by saying that “...this Qur'anic reference to God's 'promise' contains oblique allusion to the Godwilled natural law which invariably makes the rise and fall of nations dependent on their moral qualities." 136 Thus, a careful reading of the whole verse with its reference to the nations before us should suffice to counter any misunderstanding of the Qur'anic text. 


\section{B. Hadiths (reports of sayings) of the Prophet}

There are many hadiths attributed to the Prophet that use the word amir (commander) and the word caliph. I have chosen only two hadiths to illustrate the point: in the first hadith the Prophet admonishes Muslims to follow his traditions as well as those of the rightly guided caliphs: “...those of you who live after me will see great disagreement. You must then follow my Sunna and that of the rightly-guided caliphs. Hold on to it and be steadfast. ${ }^{137}$ But, as was the case in the Qur'an, the word caliph does not mean the political system of the caliphate that was established after the Prophet's death. Instead, it should be taken to mean those disciples or carriers of the Prophet's tradition succeeding one another.

In the second hadith, the Prophet seems to be prophesying the future; he is reported as saying "The caliphate in the tradition of the Prophet will last thirty years;

after that Allah will give the reign of to whomever He wills."138 This is a report of what will happen in the future. If we understand the word caliph as successor, as it was used at the time of the Prophet before its meaning evolved to connote a particular new political system, then we understand that the leaders succeeding the Prophet will follow in his footsteps for thirty years, after that there will be a different kind of leadership. Even if we assume for the sake of argument that the Prophet is talking about the caliphate as the political system the way it came to be known after his death, the statement will still be only descriptive. The Prophet here is not prescribing the caliphate system of governance, he is only endorsing its ethical spirit as far as it follows the tradition broadly established by the Qur'an and exemplified by the Prophet. 
In summary, there is nothing in the Qur'an or in the hadith that prescribes a particular form of a political system. It is the Prophet's companions who developed the caliphate after the Prophet's death in order to meet the growing needs of the evolving Muslim community.

\section{CONCLUSION}

A better understanding of the history of Islam and the Arabian culture affords us a better and nuanced understanding of the origin of the caliphate and the needs it fulfilled in its historic environment. This reappraisal of the caliphate can serve as a useful resource for Muslims and others who are trying to understand the political expression of Islamic values historically and in modernity.

It is hoped that the reader will agree that while the Prophet was a very able politician, neither did he nor did the Qur'an deliver a blue print for a governing political system or a theocracy. The Qur'an and the Prophet emphasized the major overarching principles that should guide politicians in any form of government appropriate to its historical environment. Some of the values emphasized by the Qur'an are justice, equality, human dignity, freedom of religion, peace, and mutual consultation. We saw how the disciples of the Prophet developed a governing system that expressed Islamic values appropriately in their historic environment. We also traced how the caliphate system evolved in response to changing circumstances. Whether the system is called a caliphate or not is of secondary importance. It therefore comes as no surprise that Muslim jurists never ceased their call for compliance with Islamic values throughout 
history, whether the governing system is a caliphate a sultanate, or as in our modern times, a republic or a kingdom.

A sizeable number of Muslims might consider the caliphate as a divinely mandated system headed by an exemplary leader who is just and able to rule and unify the whole Muslim community around the world as one cohesive entity. They might not attribute the absence of such a majestic caliph to mere historic evolution but rather to efforts by enemies of Islam. We discussed in this essay the historic and theological facts concerning the caliphate. We saw how the first four caliphs were selected by the community, but with the move of the capital to Damascus, the caliph's post became hereditary. The relatively rapid expansion of the territory lead to the decentralization of the 'Abbāsid caliphate resulting in many independent states with tolerance for more than one caliphate at a time. The caliphate survives today as a regional government such as we see in Morocco.

Nevertheless, the dream of a unified Muslim community guided by a virtuous caliph like 'Umar is legitimate and can be approached realistically in the modern age through a coalition of independent cooperating Muslim countries, or could simply be a spiritual nonpolitical coalition that helps Muslims all around the world keep on track in their spiritual journey on earth. Over the last 90 years, many Islamic political parties have expressed the desire to reestablish a global caliphate system some day. It is unfortunate that ISIS exploited the idea and announced the formation of an Islamic state headed by their "caliph". The scope and volume of atrocities practiced by ISIS on a daily basis makes it alien to Islamic ethical values that are essential to any caliphate. ISIS has consequently been denounced by most Muslims, including fundamentalists. 
Subsequently, Muslim leaders need to reappraise their Islamic history and tradition anew and educate the public beyond just countering the violent extremism of fringe groups. Muslim thought-leaders need to work hard at researching and reinterpreting the ethical and religious values of Islam in a contemporary language. This work should inspire and equip the young generation of Muslims to move forward in becoming agents of progress, both spiritually and intellectually for their societies and the rest of the world, just as their ancestors were in the heyday of Islam. 


\section{BIBLIOGRAPHY}

$\bar{A}$ l al-Sheikh, S. ed. Mawsu'atu al-hadith al-sharīf, al-kutubu al-sittah [Encyclopedia of Honorable Hadith-The Six Books: Sahīh Al-Bukhārì, Sahīh Muslim, Jami’ alTirmizi, Sunan Abi Dawūd, Sunan al-Nasa'i al-Sughrā, Sunan Ibn Majah]. 3rd ed. Riyadh: Darussalam, 2000.

Agnouche, Abdelatif. Histoire Politique du Maroc: Pouvoire, Legitimite, et Institutions [Political History of Morocco: Power, Legitimacy, and Institutions]. Casablanca: Afrique-Orient, 1987.

Al Arabiya News. 2014. ISIS jihadists declare 'Islamic caliphate'. June 29. http://english.alarabiya.net/en/News/2014/06/29/ISIS-jihadists-declare-caliphate.html (Accessed June 23, 2015).

Al-'Ashmawi, Muhammad Sa'id. Al-Khilafa al-Islamiyya [Islamic Caliphate]. 5th. Beirut: Mu'assasat dar al-intishar al-arabi, 2004.

Al-Banna, Gamal. al-Islam deenun wa umma, sa laisa deenan wa dawla [Islam is a Religion and Community, not a Religion and State]. Cairo: Dar al-fikr al-islami, 2003.

Al-Banna, Hasan. Majmoo'at al-imam al-shaheed Hasan al-Banna [The Martyred Imam Hassan al-Banna Collection]. Beirut: al-mu'assasa al-islamiyya lil tiba'a wa alsahafa wa al-tawzee', n. d.

Al-Mawardi, Abu al-Hasan. The Ordinances of Government. Translated by Wafaa H. Wahba. Lebanon: Garnet, 2006. 
Al-Suyuti, Jalal al-Deen Abd al-Rahman. Tarikh al-khulafa' [History of the Caliphs]. Beirut: Dar al-kutub al-ilmiyya, 2015.

Al-Tabari, Abu Ja'far. Tarikh al-Tabari al ma'roof bi tareekh al-umam wa al-muluk [History of al-Tabari, known as History of Nations and Kings]. Edited by Abd A. Ali Muhanna. 9 vols. Beirut: Mu'assasat al-A'lami liltiba'a, 1998.

Arnold, Thomas W. with a concluding chapter by Sylvia G. Haim. The Caliphate. New York: Barnes \& Noble, Inc., 1966.

Asad, Muhammad, trans. The Message of the Qur'an. Gibraltar: Dar al-Andalus, 1993.

Azmeh, Wayel. “Corporal Punishment Verses in the Qur'an Are to Be Reinterpreted to Counter Violent Extremist Practices from Within the Islamic Juristic Tradition.” DOMES 24.2 (2015): 161-186. Web.

Cockburn, Patrick. 2014. The Appeal of ISIS. July 01. http://www.counterpunch.org/2014/07/01/the-appeal-of-isis/ (Accessed June 23, 2015).

Djäit, Hichem. La Vie de Muhammad; III: le Parcours du Prophet a Medine et le Triomphe de l"Islam [The Life of Muhammad; III: His Life in Medina and the Trionph of Islam]. France: Librairie Artheme Fayard, 2012.

Donner, Fred M. "Muhammad and the Caliphate." In The Oxford History of Islam, by John L. Esposito. Oxford: Oxford University Press, 1999.

Encyclopedia Britannica. 2014. 'Abbāsid Dynasty. October 24. http://www.britannica.com/topic/Abbasid-dynasty/ (Accessed December 30, 2015). 
Esposito, John L., edit. in chief. The Oxford Encyclopedia of the Islamic World. 6 vols. Oxford: Oxford University Press, 2009.

Gibb, H.A.R. and J.H. Kramers, E. Levi-Provencal, J. Shacht. The Encyclopedia of Islam. 2nd Edition. 13 vols. Leiden: E.J. Brill, 1960.

Google Maps.. https://www.google.com/maps/ (Accessed August 09, 2015).

Haim, Sylvia G. "The Abolition of the Caliphate and its Aftermath." In The Caliphate, by Thomas Arnold. New York: Barnes \& Noble, 1966.

Haroon, Abd al-Salam. Tahdhīb Sï̄rat Ibn Hishām [A rendering of Ibn Hishaām's Biography]. Beirut: al-Majma’ al-Arabi al-Islāmi, 1954.

Hasan, Hasan Ibrahim. Tarikh al-Islam: al-siyasi, al-deeny, al-thakafi wa al-ijtima'i [History of Islam: Political, Religious, Cultural and Social]. 15th Edition. 4 vols. Beirut: Dar al-Jeel, 2001.

Hathout, Maher. Jihad Versus Terrorism. Los Angeles: The Minaret, 2001.

Haykal, Muhammad Husayn. Al-Farūk 'Umar ['Umar, the Distinguisher between right and Wrong]. 2 vols. Cairo: al-Dar al-Masiriah al-Lubnaniah, 2013.

Ibn Kathir, Isma'il abu al-Fida'. Al-Bidaya wa al-nihaya [The Beginning and the End]. Vol. 2. 14 vols. Al-Riyadh: Dar al-Shawwaf lil tiba'a wa al-Nashr, n.d.

Lewis, Bernard. The Political Language of Islam. Chicago: The University of Chicago Press, 1988.

Mones, Hussain. Atlas al-tarikh al-islami (Atlas of Islamic History). Cairo: Al-Zahraa lil I'lam al-arabi, 1987.

Munson, Henry. Religion and Power in Morocco. New Haven: Yale niversity press, 1993. 
Perry, Glenn. "Caliph." Vol. 1, in The Oxford Encyclopdia of the Islamic World, edited by John, editor in chief Esposito, 387-94. Oxford: Oxford University Press, 2009.

Peters, F.E. The Hajj: The Muslim Pilgrimage to Mecca and the Holy Places. Princeton: Princeton University Press, 1992.

Pew Research Center. 2011. Religion and Public Life. January 27. http://www.pewforum.org/2011/01/27/future-of-the-global-muslim-populationmuslim-majority/ (Accessed July 10, 2015).

Safra, J. E., ed. Encyclopedia Britannica Micropaedia. 15th ed. 12 vols. Chicago: Encyclopedia Britannica, 1998.

Sourdel, D. "Khilafa" Vol. IV, in The Encyclopedia of Islam. 2nd Edition., edited by E. Van, B.Lewis, Ch. Pellat Donzei, 945-46. Leiden: E. J. Brill, 1978.

Sourdel, D. "The 'Abbasid Caliphate." Vol. 1A, in The Cambridge History of Islam, by P.M. and Ann K.S. Lambton and Bernard Lewis Holt. Cambridge: Cambridge University Press, 2000.

Vaglieri, Laura Veccia. "The Patriarchal and Umayyad Caliphates." Vol. 1A, in The Cambridge History of Islam, by P.M. and Ann K.S. Lambton and Bernard Lewis Holt. Cambridge: Cambridge University Press, 2000.

Webster's New Universal Unabridged Dictionary. New York: Barnes \& Noble, 1996. 


\section{GLOSSARY}

\section{A}

'Abbāsids: A family that belongs to the Hashimite clan of Quraysh (the tribe of the Prophet) who were in competition with the other clan of Quraysh, the Umayyads. The Abbassids took on the caliphate from the Umayyads in $750 \mathrm{CE}$ and moved their capital to Baghdad.They Reigned until $1258 \mathrm{CE}$.

'Abbāsid Dynasty: of Caliphs from 750-1258 CE. Named for its ancestor, the uncle of the Prophet.

'Abd Allah b. al-Zubayr: Reigned in Mecca 680-692 CE at the time of the Umayyad dynasty in Damascus until he lost and was killed by the Umayyad.

Abd al-Ḥamīd I: Ottoman Sultan reigned 1774-1789 CE.

'Abd al-Malik b. Marwān: Fifth Caliph of the Umayyad line, reigned 685-705 CE. Destroyed the rival caliphate of Ibn alZubayr in Mecca 692 CE.

'Abd al-Rahmān I: Umayyad prince who fled to Spain and governed it independently, without calling himself a caliph after the 'Abbāsids took over the Umayyad Dynasty in Damascus. Reigned 756-788 CE.
'Abd al-Rahmān III: is an Umayyad ruler in Spain who proclaimed an independent Caliphate in Spain.

'Alaouīs: are a dynasty that ruled Morocco 1660-present day. It is a caliphate. I used the French spelling to distinguish them from Alawis in Syria. Oxford s.v. Mawlay

'Alawīs: (also called Nusayris) are a sect originated from Shi'a. They are more concentrated in the northwest part of Syria and south Turkey

'Alī ('Alī b. Abi Ṭalib): Cousin and son-in-law of Muhammad, fourth Caliph. Reigned 656-660 CE. Shi'a sect considers him the infallible Imam-leader considers him. Eleven infallible Imams followed from his offspring.

Abū Bakr al-Baghdadi: The leader of ISIS who declared himself a caliph in 2014 CE. Reigned 912-961 CE.

Abū Bakr al-Ṣiddīk: the first Caliph. Reigned 632-634 CE.

Abu Mohamed Al-Adnani: The spokesperson of ISIS.

Abū Ubayda (Abū Ubayda b. alJarrah): one of the early Meccan converts to Islam and leading disciples of the Prophet (d 639 CE). 
Aghlabīds: were a semi-independent dynasty who governed in the area of today's Tunisia in the name of the 'Abbāsids. They were conquered by the Fātimids. They reigned 800-909 CE.

al-'Ashmawi (Muḥammad Sa'īd al'Ashmawi): An Egyptian supreme court judge 1932-2013 CE.

al-Bukharī: One of the six most respected scholars and compilers of hadith, 810-870 (see: hadith).

al-Ḥubāb b. al-Mundhir (Al-Ḥubāb b. al-Mundhir b. al-Djamūḥ): A supporter disciple of the Prophet.

al-Hurmuzan: Persian (Farsi) general who visited Umar Ibn Al-Khattab (d 644 CE).

al-Jihad al-Islami: is an organization founded in Egypt and active in the 70's through the 90's. Plotted to destroy world trade center in New York 1993 CE.

\section{al-Mawardi (Abū al-Hasan al-} Mawardi): is a Muslim jurist known for his work on governance 972-1058 CE.

\section{al-Ṭabarī (Ja'far b. Jarīr al-Ṭabarī):} Historian and expert in tradition and law(d $923 \mathrm{CE})$.

al-Zybayr(Abd Allah b. al-Zubayr): declared himself caliph in Mecca 680 disputing the authority of the
Umayyad caliphate and was defeated and killed in $692 \mathrm{CE}$.

Ali Abd ur-Raziq: was a religious judge and and a scholar at alAzhar in Cairo (1888-1966 CE).

Almohads: established a caliphate in today's Morocco and Spain (1150-1269 CE).

Arnold, Thomas Walker: was a British orientalist (1864-1930 CE).

B

Banu Tabațaba: established a caliphate in Yemen (814-955 CE).

\section{C}

Catharine of Russia: is the most renowned and longest ruling female leader of Russia. Reigned 1762-1796 CE.

Charlemagne: was the king of the Franks and Holy Roman Emperor. Reigned 768-800 CE as King, 800-814 CE as Emperor. He was contemporaneous with Hārūn alRashīd, the 'Abbāsid caliph.

Commander of the believers (Amir alMu'mininn): The Caliph, 'Umar was the first to take the title on.

D

Djaït (Hichem Djäit): is a Tunisian Muslim historian was born in 1935 CE. 
Fatimā: is the daughter of the Prophet, wife of Ali, she died $623 \mathrm{CE}$.

Fatimìds: are a dynasty which reigned in North Africa and later Egypt from 909-1171 CE; they claim to be descended from Fatima, the Prophet's daughter.

Fay': Spoils of war taken peacefully when the enemy surrenders without fighting.

Four rightly guided caliphs: are the first leaders who succeeded the Prophet in the leadership of the Muslim community in sequence: Abū Bakr, 'Umar, 'Uthman, and 'Ali.

Franks: are Germanic-speaking people who invaded the western Roman Empire in the 5th century; they established the most powerful Christian kingdom of early medieval western Europe.

G

H

Hadith: Narration, accounts of what the Prophet said or did, or his tacit approval of what someone said or did in his presence.

Hafṣīd: A dynasty of what is today known as Tunisia. Reigned 1229$1574 \mathrm{CE}$.

Hārūn al-Rashīd: Fifth 'Abbāsid caliph, reigned 786-809 CE.
Hasan Al-Banna: The founder of the Muslim Brotherhood in Egypt (1906-1949 CE).

Hizb al-Thrīr al-Islamī: abbrev. as Tahrīr party, "The party of Islamic liberation", officially established in Jordan1953 CE to reestablish the caliphate.

Hijāz: Western part of the Arabian Peninsula, parallel to the Red Sea.

Hussain Mones: An Egyptian Muslim historian and writer 1911-1996 CE.

\section{I}

Ibn 'Abbās: One of the greatest second generation disciples of the Prophet. (d 686 CE).

Ibn 'Umar, Abdullãh: is a second generation disciple of the Prophet, son of the second Caliph 'Umar b. Al-Khattab (d 693 CE).

Ibn Hisham: is a scholar and biographer of the Prophet (d circa $828 \mathrm{CE}$ ).

Ibn Khaldūn (Abd al-Raḥman Ibn Khaldūn): is a historian and sociologist (d $1406 \mathrm{CE}$ ).

Ibn Taymiyya (Taḳiyy al-Dīn Ibn Taymiyya): is a Muslim jurist, (d $1327 \mathrm{CE}$ ).

Idrīsīds: are a Moroccan dynasty claiming descent from Ali. They reigned 789-985 CE.

\section{Immigrants (Muhādjirūn,}

Muhadjirīn): Immigrants who 
migrated with the Prophet from Mecca to Madina in $622 \mathrm{CE}$.

Isma'îlīs: are a branch of Shi'ism that believes in the infallibility of seven Imams that descended from and including Ali.

\section{$\mathbf{J}$}

Jihad: is an Arabic word that means to struggle, in Islamic rhetoric it means to struggle in the cause of God, this sometimes includes an armed struggle under specifically prescribed conditions in the Qur'an.

\section{K}

Karmatians: are an offshoot sect of Isma'îlīs. They ruled in eastern Arabia 899-1067 CE. They were at war with the 'Abbāsids.

Khalifa (caliph): is the sovereign in a traditional caliphate governing system.

Khilafa (caliphate): is the polity of the traditional caliphate system.

\section{$\mathbf{L}$}

M

Mamlūk: means slave in Arabic. "Mamluk state" is regime controlled by slave soldiers. Their capital was Cairo. They governed Egypt, Syria and western Arabia 1250-1517 CE. They ruled in the name of a puppet caliph descending from the 'Abbāsids 1250-1517 CE.
Marinīds: See Merīnids.

Mecca: is the city in west Arabia where the Prophet was born in 670 . Mecca has the Ka'ba which is a cube construct where Muslims turn to in their five daily prayers.

Medina: is the city to which the Prophet migrated in $622 \mathrm{CE}$.

Mehmed I: Ottoman Sultan, reigned 1413-1421 CE.

Merīnid: is a dynasty that ruled in today's Morocco 1269-1465 CE.

Mu'āwiyah (Mu'āwiyah b. Abī Sufyan): is one of the companions of the Prophet who belongs to the Umayyads, one of the clans of Quraysh (The Prophet's tribe). Mu'awiyah founded the Umayyad caliphate. Mu'awiyah ruled from 661-680 CE.

Mughal caliphate (1556-1857 CE): started as the Mughal Empire founded by Babur at the beginning of the sixteenth century; it included India, today's Afghanistan and Bangladesh. Akbar (d 1605 CE) declared it a caliphate in 1605 CE.

Muḥammad Anwar al-Sadat: was president of Egypt between 1970-1981 CE when he was assassinated for concluding a controversial (in the Arab world) peace treaty with Israel. 
Muhammadan: is the old name used for Muslims in Europe until mid twentieth century.

Murād I: is an Ottoman Sultan 13601389 CE.

Muslim: One of the six most respected scholars and compilers of hadith (reported sayings of Prophet Muhammad). He lived 815-875 CE.

Muslim Brotherhood: is a Muslim religious and political group founded by Hasan al-Banna in $1928 \mathrm{CE}$ with the goal of reasserting the values of Islam in society, including governance.

Mustafa Kemal Atatürk: Founder of the modern Turkish republic, abolished the Ottoman Caliphate in $1924 \mathrm{CE}$ (d $1938 \mathrm{CE})$.

\section{$\mathbf{N}$}

Nouri al-Maliki: was the prime minister of Iraq between 2006-2014 CE.

\section{$\mathbf{O}$}

Omar Abd al-Rahman: is a blind cleric who is the leader of the terrorist organization al-Jihād al-Islāmi and is serving a life sentence in the United Sates for his role in the first attack on the world trade center in New York in 1993 CE.

Ottoman: is a Turkish dynasty 1293 $1922 \mathrm{CE}$. The took on the title of caliph 1774-1922 CE. They ruled parts of Europe, Asia and Africa.

\section{$\mathbf{Q}$}

Qarmatians: see Karmatians.

Qurayshi: pertains to the Quraysh, the tribe of the Prophet in Mecca.

\section{$\mathbf{R}$}

Rustamīds (778-909 CE): are a dynasty that reigned independently in today's Algeria. They were Khawarij (the third sectarian grouping in Islam besides Sunnis and Shi'a).

$\mathbf{S}$

Sa'd b. 'Ubādaā: is a companion of the Prophet and a "supporter" from Medina.

Sa'dī: Are a dynasty that ruled Morocco 1510-1654 CE.

Sabians: (of Harran north of Syria) are a Hellenized remnant of Semitic polytheism.

Sadaka: is a religiously recommended charity that used to be paid to the Prophet.

Saddam Hussein: was the president of Irak between 1979-2003 CE.

Sahiffa (of Medina): is the pact the Prophet wrote to rights and duties of various religious groups in Medina.

Sakifat banu Sa'ida (shed of banu $\left.\boldsymbol{S a} \boldsymbol{a}^{\prime} \boldsymbol{i d a}\right)$ : is the place where an urgent meeting happened after the Prophet died to decide who will be the first community after the Prophet. The 
meeting ended up with Abū Bakr as the next caliph.

Sayyid Quṭb: was an Egyptian intellectual and a leader in the Muslim Brotherhood. He was executed in 1966 CE.

Selim I: Ottoman Sultan reigned 15121520 CE. He conquered Egypt in 1517 CE.

Shām: Includes what is now called greater Syria, including Syria, Lebanon, Jordan and Palestine.

Sheikh al-Azhar (shaykh al-Azhar):

The head of al-Azhar university in Cairo. Al-Azhar is one of the most prestigious traditional Islamic institutions. It was founded in $970 \mathrm{CE}$.

Shia (Shi'a): Muslim sect represents $10-13 \%$ of Muslims based on the concept that the leadership and caliphate after the Prophet should have gone to the Prophet's cousin 'Ali and then 11 descendants after him who are believed to be infallible.

Sulțan: is a ruler who might be independent or affiliated with a caliph.

\section{T}

Tâa'if: A town in Arabia to the South east of Mecca.

Tabaristan: is an area north Iran, from where the classical historian al-Tabari name comes from.

Tabaristan caliphate (864-956 CE): was in notern Iran close to the Caspian sea.
Tabūk: Town in northwestern Arabia.

Tahrir party: See Hizb al-Tahrir alIslami).

Tirmidhi: One of the six most respected scholars and compilers of hadith (reported sayings of Prophet Muhammad). He died 892 CE (see hadith).

\section{$\mathbf{U}$}

'Umar ('Umar b. al-Khațtab): is the second and one of the four rightly guided caliphs reigned 334-344 CE.

'Utba b. Rabi'a: is one of the leadership of the pagan Quraysh (d circa $624 \mathrm{CE}$ ).

'Uthmān ('Uthmān b. 'Affan): is the third and one of the four RightlyGuided Caliphs. 'Uthmān reigned 644-655 $\mathrm{CE}$.

Umayyads: (Umayyad: are one of the clans of Quraysh. They have been in rivalry with one of the other clans of Quraysh, namely the Hashimites to which belongs the Prophet, his cousin Ali and the Prophet's uncle al-Abbas. The Umayyads took on the caliphate in $661 \mathrm{CE}$ and moved their capital to Damascus (this caliphate is referred to as Umayyads I in Damascus in this essay). When the "Abbāsids took over the caliphate from the Umayyads in Damascus and moved the capital to Bagdad in $750 \mathrm{CE}$, the only Umayyad prince that survived fled to Spain, one of his offspring established another caliphate in $912 \mathrm{CE}$ referred to as (Umayyad II caliphate in Cordoba) in this essay. 
Umayyads II in Cordoba: (see also Umayyads I in Damascus). The

'Abbāsid dynasty was founded in 750 $\mathrm{CE}$ at the expense of the Umayyads. Abd al-Rahman I managed to escape and found an independent Umayyad dynasty in Spain contemporary with the 'Abbāsids in 756 CE.

\section{V \\ W \\ $\mathbf{X}$ \\ Y}

Yathrib: is the pre-Islamic name of Medina.

\section{$\mathbf{Z}$}

Zakat: Or poor due, is a religiously mandated alms.

Zaydis: are an early branch of Shi'a Islam that follow the Imam Zayd b. Ali. Most of the Zaydis are in Yemen. They formed four dynasties in Yemen at different times as detailed in table 3 .

Zorozstrianism: are dherents to Zoroastrianism, the ancient religion of Iran before Islam. It was founded by the Iranian Prophet Zoroaster in the $6^{\text {th }}$ century BCE. It is a monotheistic religion. 


\section{FOOTNOTES}

${ }^{1}$ By Islam here, I mean both the religion of Islam as well as the history of Islam.

${ }^{2}$ Caliphate, or khilafa-in Arabic: "n. the rank, jurisdiction, or government of a caliph." See Webster's New Universal Unabridged Dictionary, $2^{\text {nd }}$ ed., s.v. "caliphate (polity) .'C

${ }^{3}$ Al Arabiya News. ISIS jihadists declare 'Islamic caliphate.' June 29, 2014. http://english.alarabiya.net/en/News/2014/06/29/ISIS-jihadists-declare-caliphate -.html (accessed June 23, 2015).

${ }^{4}$ Patrick Cockburn, The Appeal of ISIS. July 01, 2014.

http://www.counterpunch.org/2014/07/01/the-appeal-of-isis/ (accessed June 23, 2015).

${ }^{5}$ Mustafa Kemal Atatürk: Founder of the modern Turkish republic, abolished the Ottoman Caliphate in 1924 CE (d 1938 CE). See The Oxford Encyclopedia of the Islamic World, s.v. Atatürk, Mustafa Kemal, 1:345.

${ }^{6}$ Pew Research Center. Religion and Public Life. January 27, 2011. http://www.pewforum.org/2011/01/27/future-of-the-global-muslim-population-muslimmajority/ (accessed July 10, 2015).

${ }^{7}$ Caliph: " $n$. 1. a spiritual leader of Islam, claiming succession from Muhammad. 2. Any of the former rulers of Baghdad 'until $1258 \mathrm{CE}$ ' and of the Ottoman empire 'from 1517 CE until 1924 CE.'” See Webster's New Universal Unabridged Dictionary, $2^{\text {nd }}$ ed., s.v. "caliph." Actually many scholars such Bernard Lewis and D. Sourdel and glenn E. Perry argue that the Ottomans did not claim their dominion as a Caliphate consistently until 1774 CE. See Bernard Lewis, The Political Language of Islam. (Chicago: The University of Chicago Press, 1988), 49; D. Sourdel, "Khilāfa." Vol. IV, in The Encyclopedia of Islam. $2^{\text {nd }}$ edition. Edited by E. Van, B.Lewis, Ch. Pellat Donzei, 94546. (Leiden: E. J. Brill, 1978; Perry, Glenn. Caliph. Vol. 1, in The Oxford Encyclopdia of the Islamic World, edited by John Esposito, 387-94. (Oxford: Oxford University Press, 2009).

${ }^{8}$ Lewis, The Political Language of Islam, 43. 
${ }^{9}$ All dates in this essay are in the common era-CE, rather than the traditional hijra calendar for the sake of simplicity and uniformity.

${ }^{10}$ Perry, "caliph," The Oxford Encyclopedia of the Islamic World. 387-94.

${ }^{11}$ Lewis, Political Language of Islam, 46.

${ }^{12}$ One of the stories informing us about the origin of this title is recorded by alTabari (d 922 CE): When Omar took office, he was called khalifa of khalifa of the Messenger of God; Omar "may God be pleased with him" said: "this is a lengthening thing, every time a khalifa comes they say: 'khalifa of khalifa of the Messenger of God'! You re the believers and I am your commander," so he was called the commander of the believers. Abu Ja'far Al-Tabari, Tarikh al-Tabari al ma'roof bi tareekh al-umam wa almuluk [History of al-Tabari, known as History of Nations and Kings]. Edited by Abd A. Ali Muhanna. 9 vols. (Beirut: Mu'assasat al-A'lami liltiba'a, 1998), 3:583 (unless otherwise noted, all translations are my own). All translations from Arabic in this essay are mine unless stated otherwise.

${ }^{13}$ See Laura Veccia Vaglieri. "The Patriarchal and Umayyad Caliphates." Vol. 1A, in The Cambridge History of Islam, by P.M. and Ann K.S. Lambton and Bernard Lewis Holt. (Cambridge: Cambridge University Press, 2000), 57-58; See also Hasan Ibrahim Hasan. Tarikh al-Islam: al-siyasi, al-deeny, al-thakafi wa al-ijtima'i [History of Islam: Political, Religious, Cultural and Social]. 15th Edition. 4 vols. (Beirut: Dar alJeel, 2001), 1:355-56; see also The Oxford Encyclopedia of the Islamic World, s.v. "Caliph", 1:388-90; see also D. Sourdel, "Khilāfa," in The Encyclopedia of Islam, 937.

${ }^{14}$ Mu'āwiyah (Mu'āwiyah b. Abī Sufyān): Companion of the Prophet who belongs to the Umayyads, one of the clans of Quraysh (The Prophet's tribe). Mu'āwiyah founded the Umayyad caliphate (polity). Mu'āwiyah ruled from 661-680 CE. See The Oxford Encyclopedia of the Islamic World, s.v. "Mu'āwiyah Ibn Abī Sufyān", 4: 89.

${ }^{15}$ Umayyads: One of the clans of Quraysh (the Prophet's tribe). They have been in rivalry with one of the other clans of Quraysh, namely the Hashimites to which belongs the Prophet, his cousin Ali and the Prophet's uncle al-Abbas. The Umayyads took on the caliphate in $661 \mathrm{CE}$ and moved their capital to Damascus. The Umayyads ruled from Damascus 661-750 CE when the 'Abbāsids took on the caliphate (polity) for themselves ending the Umayyad caliphate (polity). An Umayyad prince (Abd al-Rahman I) managed to escape alive and founded an Umayyad emirate in Spain in 755 CE. His descendent Abd al-Rahman III, the eighth Umayyad prince to govern in Muslim Spain declared a new caliphate (polity) in 929 CE. The Oxford Encyclopedia of the Islamic World, s.v. Umayyad Caliphate 5:453 and s.v. Andalusia1:143. For this essay when referring of Umayyads governemnt in Spain, they will be referred to as Umayyads II in cordoba.

16 'Abbāsids: A family that belongs to the Hashimite clan of Quraysh (the tribe of the Prophet) who were in competition with the other clan of Quraysh, the Umayyads. The 'Abbāsids took on the caliphate (polity) from the Umayyads in $750 \mathrm{CE}$ and moved their 
capital to Baghdad. See Esposito, The Oxford Encyclopedia of the Islamic World. s.v. “"Abbaāsid Caliphate," 1:2.

${ }^{17}$ Mamluk: means slave in Arabic. "Mamluk state" is regime controlled by slave soldiers. Their capital was Cairo. They governed Egypt, Syria and western Arabia 1250$1517 \mathrm{CE}$. They ruled in the name of a puppet caliph descending from the 'Abbāsids 1250-1517 CE. See The Oxford Encyclopedia of the Islamic World, s.v. M"amlūk State," 3:483.

${ }^{18}$ Contrary to a common story that claims the 'Abbāsid puppet caliph passed on the caliphate to the Ottoman sultan Selīm I, many scholars such Bernard Lewis and D. Sourdel and glenn E. Perry argue that the Ottomans did not claim their dominion as a Caliphate consistently until 1774 CE. See Bernard Lewis, The Political Language of Islam, 49; D. Sourdel, "Khilāfa", The Encyclopedia of Islam IV: 945; Perry, "Caliph", The Oxford Encyclopdia of the Islamic World, 1:387.

${ }^{19}$ Abd al-Hamīd I: Ottoman Sultan reigned 1774-1789 CE. See The Encyclopedia of Islam, s.v. 'Abd al-Hamīd I, I:62.

${ }^{20}$ D. Sourdel, "Khilāfa", The Encyclopedia of Islam, $2^{\text {nd }}$ edition."

${ }^{21}$ Lewis, The Political Language of Islam, 50.

${ }^{22}$ Almohads (1150-1269 CE) were a dynasty who declared themselves as a caliphate (polity). They ruled Southern Spain and today's Morocco. See The Oxford Encyclopedia of the Islamic World. s.v. "Muwaḥhdūn" 4:200-03; Hussain Mones. Atlas al-tarikh al-islami [Atlas of Islamic History]. (Cairo: Al-Zahraa lil I'lam al-arabi, 1987).

${ }^{23}$ an early branch of Shi'a Islam that follow the Imam Zayd b. Ali (d $\left.740 \mathrm{CE}\right)$. Most of the Zaydis are in Yemen. They formed four caliphates in Yemen at different times as detailed in table 3. See, The Oxford Encyclopdia of the Islamic World, s.v. "Shi' 1 Islam", 5:139.

${ }^{24}$ Sylvia G. Haim. "The Abolition of the Caliphate and its Aftermath." In The Caliphate, by Thomas Arnold. (New York: Barnes \& Noble, 1966), 235-36.

${ }^{25}$ Hasan al-Banna founded the Muslim Brotherhood in 1928 CE. See Hasan AlBanna, Majmoo'at al-imam al-shaheed Hasan al-Banna [The Martyred Imam Hasan alBanna Collection]. (Beirut: al-mu'assasa al-islamiyya lil tiba'a wa al-sahafa wa altawzee', n. d.), 5.

${ }^{26}$ H. al-Banna, Majmoo'at al-imam al-shaheed, 178.

${ }^{27}$ Ibid, 223-24. 
${ }^{28} \mathrm{Hizb}$ al-Tahrir was officially born in in $1953 \mathrm{CE}$. Its founders were Taqiuddin al-Nabhani, Daoud Hamdan, and Nimr al-Misri. They are Palestinian religious clerics. The Jordanian government refused to grant license to the nascent political party. The three leaders spent their lives alternating between different prisons and hiding in the Levant. See Gamal Al-Banna, al-Islam deen wa umma, sa laisa deenan wa dawla [Islam is a Religion and Community, not a Religion and State]. (Cairo: Dar al-fikr al-islami, 2003), 316-17.

${ }^{29}$ G. al-Banna, al-Islam deen wa umma, 320.

${ }^{30}$ Migration from Mecca to Medina, 622.

${ }^{31}$ See G. al-Banna, al-Islam deen wa umma, 315-323.

$32 \mathrm{Jihad}$ is an Arabic word that means to struggle, in Islamic rhetoric it means to struggle in the cause of God, this sometimes includes an armed struggle under specifically prescribed conditions in the Qur'an. See: Maher Hathout. Jihad Versus Terrorism. (Los Angeles: The Minaret, 2001).

${ }^{33}$ See The Oxford Encyclopdia of the Islamic World, s.v. "Banna, Hasan al-"; see also G. al-Banna, al-Islam deenun wa umma, p 282.

${ }^{34}$ See G. al-Banna, al-Islam deen wa umma, 325-334.

35 'Umar b. al-Kh hatțāb is the second and one of the four rightly guided caliphs reigned 334-344 CE. See The Oxford Encyclopdia of the Islamic World, s.v. "Umar b.

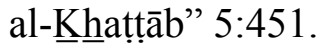

${ }^{36}$ Hāruūn al-Rashīd is Fifth 'Abbāsid caliph, reigned 786-809 CE. See The Oxford Encyclopdia of the Islamic World, s.v. "Harūn al-Rashīd”, 2:380.

${ }^{37}$ Laura Veccia Vaglieri. The Patriarchal and Umayyad Caliphates. Vol. 1A, in The Cambridge History of Islam, by P.M. and Ann K.S. Lambton and Bernard Lewis Holt. (Cambridge: Cambridge University Press, 2000), 64.

${ }^{38}$ Muhammad Husayn Haykal. Al-Farūk 'Umar ['Umar, the Distinguisher between right and Wrong]. 2 vols. (Cairo: al-Dar al-Masiriah al-Lubnaniah, 2013), 607.

${ }^{39}$ Hasan. Tarikh al-Islam: al-siyasi, al-deeny, al-thakafi wa al-ijtima'i [History of Islam: Political, Religious, Cultural and Social],1:203. 
${ }^{40}$ Fred M. Donner, "Muhammad and the Caliphate." In The Oxford History of Islam, by John L. Esposito. (Oxford: Oxford University Press, 1999), 47.

${ }^{41}$ Encyclopedia Britannica. 2014. 'Abbāsid Dynasty. October 24. http://www.britannica.com/topic/Abbasid-dynasty/ (Accessed December 30, 2015).

${ }^{42}$ Rustamīds (778-909 CE) are a dynasty that reigned independently in today's Algeria. They were Khawarij (the third sectarian grouping in Islam in addition to Sunnis and Shi'a). The Oxford Encyclopedia of the Islamic World, s.v. "Khawarijj," 3:327-28.

${ }^{43}$ Idrīsīids Moroccan dynasty of descendants of Ali, they reigned 789-985 CE, but did not declare themselves as a caliphate. See Abdelatif Agnouche. Histoire Politique du Maroc: Povoire, Legitimite, et Institutions [Political History of Morocco: Power, Legitimacy, and Institutions]. (Casablanca: Afrique-Orient, 1987), 170.

${ }^{44}$ Aghlabīds (800-909 CE) were a semi-independent dynasty who governed in the area of today's Tunisia in the name of the "Abbāsids. They were conquered by the Fātimids. The Oxford Encyclopedia of the Islamic World, s.v. "Aghlabids," 4:448.

${ }^{45}$ D. Sourdel. The "Abbāsid Caliphate. Vol. 1A, in The Cambridge History of Islam, by P.M. and Ann K.S. Lambton and Bernard Lewis Holt. (Cambridge: Cambridge University Press, 2000),117-118.

${ }^{46}$ Umayyad II in Spain (929-1030 CE): when the "Abbāsids took over the caliphate (polity) from the Umayyads in Damascus and moved the capital to Bagdad in $750 \mathrm{CE}$, the only Umayyad prince that survived fled to Spain, one of his offspring established another caliphate in 912 CE, referred to as Umayyad II caliphate in Cordoba in this essay.

${ }^{47}$ Karmatians: are an offshoot sect of Isma'îlis. They ruled in eastern Arabia 899$1067 \mathrm{CE}$. They were at war with the "Abbāsids. The Encyclopedia of Islam. $2^{\text {nd }}$ edition, s.v. "Karmatī," IV:660.

${ }^{48}$ Charlemagne: was the king of the Franks and Holy Roman Emperor. Reigned 768-814 CE as he became Emperor in $800 \mathrm{CE}$. He was contemporaneous with Hārūn alRashīd, the 'Abbāsid caliph. See J. E. Safra, ed. Encyclopedia Britannica Micropaedia. 15th ed. 12 vols. (Chicago: Encyclopedia Britannica, 1998), s.v. "Charlemagne," 3:103.

${ }^{49}$ Franks: Germanic-speaking people who invaded the western Roman Empire in the 5th century; they established the most powerful Christian kingdom of early medieval western Europe. See See J. E. Safra, ed. Encyclopedia Britannica Micropaedia, s.v. "Frank," 4:936.

${ }^{50}$ Hasan, Tarikh al-Islam, 2: 55; Sourdel, "The "Abbāsid Caliphate", 118. 
${ }^{51}$ Ibn Taymiyya (Taḳiyy al-Dīn Ibn Taymiyya): is a Muslim jurist, (d 1328 CE). See The Oxford Encyclopedia of the Islamic World, s.v. "Ibn Taymiyah," 2:502.

${ }^{52}$ Ibn Khaldūn (Abd al-Raḥmān Ibn Khaldūn): is a historian and sociologist (d 1406 CE). See The Oxford Encyclopedia of the Islamic World, s.v. "Ibn Khaldūn," 2:493.

${ }^{53}$ Extracted from Mones, Atlas al-tarikh al-islami, 36-41.

${ }^{54}$ Ibid.

${ }^{55}$ Sabians: (of Harran north of Syria) are a Hellenized remnant of Semitic polytheism. The Encyclopedia of Islam. $2^{\text {nd }}$ edition, s.v. "Șābi'," VIII:672.

${ }^{56}$ Zoroastrians: are adherents to Zoroastrianism, the ancient religion of Iran before Islam. It was founded by the Iranian Prophet Zoroaster in the $6^{\text {th }}$ century BCE. It is a monotheistic religion. See Encyclopedia Britannica Micropaedia, s.v. zoroastrianism, $12: 935$.

${ }^{57}$ Google Maps. https://www.google.com/maps (accessed 08 09, 2015).

58 The speed of a Hijazi camel is estimated at 2 miles per hour. To maintain the pace, the traveler had to be in saddle 12 hours every 24 hours. This is Richard Burton's estimation. See F.E. Peters. (Princeton: Princeton University Press, 1992), 72

${ }^{59}$ Hussain Mones: is an Egyptian Muslim historian and writer 1911-1996 CE.

${ }^{60}$ Abd Allah b. al-Zubayr: declared himself caliph in Mecca $680 \mathrm{CE}$ disputing the authority of the Umayyad caliphate and was defeated and killed in 692 CE. See The Encyclopedia of Islam. $2^{\text {nd }}$ edition, s.v. “Abd Allah b. al-Zubayr,” I:54.

${ }^{61}$ Abd al-Malik b. Marwān: is the fifth Caliph of the Umayyad line (Umayyad I in Damascus), reigned 685-705 CE. Destroyed the rival caliphate of Ibn al-Zubayr in Mecca 692 CE. See The Encyclopedia of Islam. $2^{\text {nd }}$ edition, s.v. “Abd al-Malik b. Marwān,” I:76.

${ }^{62}$ Fatimīds: are a dynasty which reigned in North Africa and later Egypt from 909-1171 CE; claim to be descended from Fatima. See The Oxford Encyclopedia of the Islamic World, s.v. "Fațimīd Dynasty," 2:228.

${ }^{63}$ And the Moroccan kings are quite conscious of it, and proud to take the official caliph title of the "commander of the faithful." In 1979 CE the previous king of Morocco Hasan II declared on the occasion of official nomination of a general as head of the army's southern zone: "anyone we entrust with a civil or military mission must reflect our mission, that of the commander of the faithful... On another occasion, Hasan II was taking the bay'a [pledge of allegiance to legitimize his sovereignty as caliph] from notables of the Western Sahara. This was necessary from an Islamic legal point of view to make the reign of the recently independent ex-Spanish colony valid. The notables said: 
“...We tribes of Oulad Dlim, Ait Lahsen...have decided by general agreement, without exception and with unanimity that excludes all error, to renew our oath of allegiance [bay'a] to the commander of the faithful...the object of which is the same as the oath sworn to the Prophet under the blessed tree [shajarat al-ridwan]..." Henry Munson, Religion and Power in Morocco. (New Haven: Yale niversity press, 1993). 127-128.

${ }^{64}$ Mones, Hussain. Atlas al-tarikh al-islami (Atlas of Islamic History). Cairo: AlZahraa lil I'lam al-arabi, 1987.

${ }^{65}$ Banu Țabațaba (814-955 CE): established a caliphate (polity) in Yemen 814955 CE. See Jalal al-Deen Abd al-Rahman Al-Suyuti. Tarikh al-khulafa' [History of the Caliphs]. (Beirut: Dar al-kutub al-ilmiyya, 2015), 342.

${ }^{66}$ Tabaristan caliphate (864-956 CE). See Al-Suyuti, Tarikh al-khulafa', 343. Tabaristan is an area north Iran, from where the classical historian al-Tabari name comes from. See The Oxford Encyclopedia of the Islamic World, s.v. "Tabarī, Abū Ja' fār Muḥammad Ibn Jarīr Al-" 5:287.

${ }^{67}$ Zaydis I caliphate ruled 943-1018 CE in Yemen. See Mones, Atlas al-tarikh alislami, 36-41; see also Zaydis in note 23 above.

${ }^{68}$ Hafsīds (1230-1574 CE): A dynasty of what is today known as Tunisia, they declared themselves caliphs one year after the sack of Baghdad in 1259 CE. See Hasan, Tarikh al-Islam, 4:302.

${ }^{69}$ Marīnīds also spelled Merīnīds (1269-1465 CE): is a dynasty ruled in today's Morocco. Hasan, Tarikh al-Islam, 4:304.

${ }^{70}$ Sa'di caliphate (1510-1658 CE): Sa'dis were a dynasty that ruled Morocco 1510-1654 CE. See The Oxford Encyclopdia of the Islamic World, s.v. "Mawlay, 535;" See also Agnouche, Histoire Politique du Maroc, 181. Agnouche states they claimed a caliphate

${ }^{71}$ Mughal caliphate (1556-1857 CE): started as the Mughal Empire founded by Babur at the beginning of the sixteenth century; it included India, today's Afghanistan and Bangladesh. Akbar (d $1605 \mathrm{CE}$ ) declared it a caliphate in $1605 \mathrm{CE}$. See The Oxford Encyclopdia of the Islamic World, s.v. Mughal Empire, 93.

72 Zaydis II caliphate ruled 1636-1805 CE. See Mones, Atlas al-tarikh al-islami, 36-41; see also Zaydis in note 23 above.

73 'Alawid I caliphate reigned 1658-1912 CE): the 'Alawid s are a Sunni dynasty that ruled Morocco 1660-present day. Their rule became only nominal under the French mandate between 1912 CE and 1956 CE. It is a caliphate. See The Oxford Encyclopdia of the Islamic World, s.v. "Mawlay," 3:531; “"Alawid Dynasty," 1:101; Mones, Atlas al- 
tarikh al-islami, 36-41. The Alawids are not to be confused with 'Alawites: (also called Nușayriyah) who are a sect originated from Shi'a. They are more concentrated in the northwest part of Syria and south Turkey. See The Oxford Encyclopdia of the Islamic World, s.v. "Alawīyah," 1:105.

${ }^{74}$ Ottoman Caliphate (1774-1924 CE). Osman I founded the Ottoman dynasty (d $1324 \mathrm{CE}$ ). It took on the title of caliphate in $1774 \mathrm{CE}$. See The Oxford Encyclopdia of the Islamic World, s.v. "Caliph," 1:390; "Sanjak," 5:49.

${ }^{75}$ Sokoto caliphate (1804-1903 CE). It lost its stately power under the British rule but continued as a very influential religious institution since Nigeria's independence in 1960 CE. See The Oxford Encyclopdia of the Islamic World, s.v. "Sokoto Caliphate," $5: 186$.

${ }^{76}$ Zaydis III caliphate ruled 1840-1871 CE. See Mones, Atlas al-tarikh al-islami, 36-41. See also Zaydis in note 23 above.

${ }^{77}$ Zaydis IV caliphate ruled 1920-1963 CE. Mones, Atlas al-tarikh al-islami, 3641. See also Zaydis in note 23 above.

78 'Alawid II caliphate (polity)has ruled since 1956-presently. See note 72. The 'Alawid caliphate (polity) became only nominal in 1912-1956 CE under the French mandate. See Mones, Atlas al-tarikh al-islami, 36-41.

${ }^{79}$ Abd al-Rahman III: is an Umayyad ruler in Spain who proclaimed an independent Caliphate in Spain. Reigned 912-961 CE. See The Oxford Encyclopdia of the Islamic World, s.v. "Andalusia”:143.

${ }^{80}$ The first verse talks about Adam symbolizing all humanity as a delegatekhalifa, one who will be in charge of earth; "2:30 AND LO! Thy Sustainer said unto the angels: 'Behold, I am about to establish upon earth one who shall inherit it.' They said: 'Wilt Thou place on it such as will spread corruption thereon and shed blood -whereas it is we who extol Thy limitless glory, and praise Thee, and hallow Thy name?' [God] answered: 'Verily, I know that which you do not know.' The second verse reminds David of his role as a delegate-khalifa, vicegerent on earth and then commands him to judge among people with justice: 38:26 [And We said:] 'O David! Behold, We have made thee a [prophet and, thus, Our] vicegerent on earth: judge, then, between men with justice, and do not follow vain desire, lest it lead thee astray from the path of God: verily, for those who go astray from the path of God there is suffering severe in store for having forgotten the Day of Reckoning!"' (The Qur'an), see Muhammad Asad, trans. The Message of the Qur'an. (Gibraltar: Dar al-Andalus, 1993). All Qur'anic verse translation in this essay are from Muhammad Asad unless stated otherwise.

${ }^{81}$ See Muhammad Sa'id Al-'Ashmawi. Al-Khilafa al-Islamiyya [Islamic Caliphate]. 5th. Beirut: Mu'assasat dar al-intishar al-arabi, 2004, 165. 
82 " $27: 62$ Nay - who is it that responds to the distressed when he calls out to Him, and who removes the ill [that caused the distress], and has made you inherit the earth? Could there be any divine power besides God? How seldom do you keep this in mind!" (The Qur'an).

83 '2:251 And thereupon, by God's leave, they routed them. And David slew Goliath; and God bestowed upon him dominion, and wisdom, and imparted to him the knowledge of whatever He willed.

And if God had not enabled people to defend themselves against one another, corruption would surely overwhelm the earth: but God is limitless in His bounty unto all the worlds" (The Qur'an).

84 "27:34 Said she: "Verily, whenever kings enter a country they corrupt it, and turn the noblest of its people into the most abject. And this is the way they [always] behave?; 18:79 "As for that boat, it belonged to some needy people who toiled upon the sea -and I desired to damage it because (I knew that] behind them was a king who is wont to seize every boat by brute force" (The Qur'an).

${ }^{85}$ See Lewis, The Political Language of Islam, 35.

${ }^{86}$ See al-`Ashmawī, Al-Khilafa al-Islamiyya, 75.

${ }^{87}$ See Lewis, The Political Language of Islam, 36.

88 " $5: 42$ those who eagerly listen to any falsehood, greedily swallowing all that is evil! Hence, if they come to thee [for judgment], thou mayest either judge between them or leave them alone: for, if thou leave them alone, they cannot harm thee in any way. But if thou dost judge, judge between them with equity: verily, God knows those who act equitably" (The Qur'an).

89 “4:58 BEHOLD, God bids you to deliver all that you have been entrusted with unto those who are entitled thereto, and whenever you judge between people, to judge with justice. Verily, most excellent is what God exhorts you to do: verily, God is allhearing, all-seeing!" (The Qur'an).

90 " $12: 22$ And when he reached full manhood, We bestowed upon him the ability to judge [between right and wrong], as well as [innate] knowledge: for thus do We reward the doers of good" (The Qur'an).

91 " $5: 44$ Verily, it is We who bestowed from on high the Torah, wherein there was guidance and light. On 'its strength did the prophets, who had surrendered themselves unto God, deliver judgment unto those who followed the Jewish faith; and so did the [early] men of God and the rabbis, inasmuch as some of God's writ had been entrusted to their care; and they [all] bore witness to its truth. Therefore, [O children of Israel,] hold 
not men in awe, but stand in awe of Me; and do not barter away My messages for a trifling gain: for they who do not judge in accordance with what God has bestowed from on high are, indeed, deniers of the truth! 5:45 And We ordained for them in that [Torah]: A life for a life, and an eye for an eye, and a nose for a nose, and an ear for an ear, and a tooth for a tooth, and a [similar] retribution for wounds; but he who shall forgo it out of charity will atone thereby for some of his past sins. And they who do not judge in accordance with what God has revealed - they, they are the evildoers!" (The Qur'an).

92 " $5: 47$ Let, then, the followers of the Gospel judge in accordance with what God has revealed therein: for they who do not judge in the light of what God has bestowed from on high-it is they, they who are truly iniquitous!"' (The Qur'an).

93 See Lewis, The Political Language of Islam, 32.

94 " $42: 38$ and who respond to [the call of] their Sustainer and are constant in prayer; and whose rule [in all matters of common concern] is consultation among themselves; and who spend on others out of what We provide for them as sustenance" (The Qur'an).

95 3:159 And it was by God's grace that thou [O Prophet] didst deal gently with thy followers: for if thou hadst been harsh and hard of heart, they would indeed have broken away from thee. Pardon them, then, and pray that they be forgiven. And take counsel with them in all matters of public concern; then, when thou hast decided upon a course of action, place thy trust in God: for, verily, God loves those who place their trust in Him" (The Qur'an). see commentary on this verse in Asad, The Message of the Qur'an, $3: 159$.

${ }^{96}$ Hichem Djäit. La Vie de Muhammad; III: le Parcours du Prophet a Medine et le Triomphe de l"Islam [The Life of Muhammad; III: His Life in Medina and the Trionph of Islam]. (France: Librairie Artheme Fayard, 2012), 88-102.

${ }^{97}$ Lewis, The Political Language of Islam, 113.

${ }^{98}$ Muhammad b. Ishạa....said: "Some tribes of Quraysh called for an alliance, they met at the house of Abd Allah b. Jud'ān...they committed and promised each other to stand with any oppressed in Mecca whether a native or other among those who enter Mecca of the rest of people, in solidarity with him against the oppressor until injustice is reversed. Quraysh (the Prophet's tribe) call that alliance the alliance of $f u d \bar{u} l . "$

Muhammad b. Ishak said...The messenger of God said: "I have witnessed at the house of Abd Allah b. Jud'ān an alliance I would not have abandoned it even in exchange for red camels, if I would be asked to join it in Islām I would. Isma'il abu al-Fida' Ibn Kathir,. AlBidaya wa al-nihaya [The Beginning and the End]. Vol. 2. 14 vols. Al-Riyadh: Dar alShawwaf lil tiba'a wa al-Nashr, n.d., 330.

99 al-'Ashmawī, Al-Khilafa al-Islamiyya, 143-145. 
${ }^{100}$ Abd al-Salam Haroon. Tahdhīb Siürat Ibn Hishām [A rendering of Ibn Hishaām's Biography]. (Beirut: al-Majma' al-Arabi al-Islāmi, 1954), 140.

${ }^{101}$ Djäit, La Vie de Muhammad, 89.

${ }^{102}$ Ibid, 252.

${ }^{103}$ Haroon, Tahdhīb Siīrat Ibn Hishām, 72-73.

${ }^{104}$ Ibid.

105 al-'Ashmawi, Al-Khilafa al-Islamiyya, 152-153.

${ }^{106}$ Djäit, La Vie de Muhammad, 84.

${ }^{107}$ al-'Ashmawi, Al-Khilafa al-Islamiyya, 152-153.

${ }^{108}$ Ibid, 154.

109 " $9: 103$ [Hence, O Prophet,] accept that [part] of their possessions which is offered for the sake of God, so that thou mayest cleanse them thereby and cause them to grow in purity, and pray for them: behold, thy prayer will be [a source of] comfort to them-for God is all-hearing, all-knowing" (The Qur'an).

110 " $59: 7$ Whatever [spoils taken] from the people of those villages God has turned over to His Apostle - [all of it] belongs to God and the Apostle, and the near of kin [of deceased believers], and the orphans, and the needy, and the wayfarer, so that it may not be [a benefit] going round and round among such of you as may [already] be rich. Hence, accept [willingly] whatever the Apostle gives you [thereof], and refrain from [demanding] anything that he withholds from you; and remain conscious of God: for, verily, God is severe in retribution" (The Qur'an).

111 al-'Ashmawī, Al-Khilafa al-Islamiyya 154-155; see also Djäit, p 291; and alBanna, G., al-Islam deenun wa umma, 38-39.

${ }^{112}$ Djäit, La Vie de Muhammad, 292.

${ }^{113}$ See al-Banna, G., al-Islam deenun wa umma, 29-33.

${ }^{114}$ Djäit, La Vie de Muhammad, 308.

${ }^{115}$ Ibid, 280.

${ }^{116}$ Ibid, 309. 
117 al-‘Ashmawī, Al-Khilafa al-Islamiyya, 168-169.

${ }^{118}$ Ibid 178.

${ }^{119}$ Al-Tabari, Tarikh al-Tabari, 3: 81.

${ }^{120}$ Haroon, Tahdhīb Sī̄rat Ibn Hishām, 393.

${ }^{121}$ Ibid.

${ }^{122}$ Al-Tabari, Tarikh al-Tabari, 3: 83.

123 Ibid.

${ }^{124}$ Ibid, 3: 84.

125 Ibid.

${ }^{126}$ Alluding to the verse in the Qur'an that mentions the two in the cave hiding on their way of migration from Mecca to Medina, one of the them is the Prophet and the second is Abū Bakr. This is supported by a hadith authenticated by al-Bukharī, the Prophet's saying to Abu Bakr, on that very occasion, "What [could], in thy opinion, [happen] to two [men] who have God as the third with them?" (Bukhari: Hadith 4662).

See S. Āl al-Sheikh, ed. Mawsu'atu al-hadith al-sharīf, al-kutubu al-sittah [Encyclopedia of Honorable Hadith-The Six Books: Sahīh Al-Bukhārì, Sahīh Muslim, Jami' al-Tirmizi, Sunan Abi Dawūd, Sunan al-Nasa'i al-Sughrā, Sunan Ibn Majah]. 3rd ed. (Riyadh: Darussalam, 2000), 386.

Here is the Qur'anic verse: "9:40 If you do not succour the Apostle, then [know that God will do so -just as] God succoured him at the time when those who were bent on denying the truth drove him away, [and he was but] one of two: when these two were [hiding] in the cave, [and] the Apostle said to his companion, 'Grieve not: verily, God is with us.' And thereupon God bestowed upon him from on high His (gift of] inner peace, and brought utterly low the cause of those who were bent on denying the truth, whereas the cause of God remained supreme: for God is almighty, wise" (The Qur'an).

${ }^{127}$ According to a narration after Ibn 'Abbas: "Umar said...the pledge of allegiance to Abú Bakr [an Immigrant] was a spontaneous occurrence...but God shielded its evil...we learned when God took back his Prophet [when the Prophet died] that Ali and al-Zybayr and their companions lagged behind at the house of Fatimā [the daughter of the Prophet], and all the Ansār [Supporters] lagged as well, the Muhādjirūn [Immigrants] agreed on Abū Bakr [as a leader]; I told Abū Bakr: 'Let's go to our Ansār brothers, on our way we encountered two good men who had witnessed the battle of Badr, they said: where are you heading O'Muhadjirīn? We said: we are seeking our Ansār brothers. They said: Go back and settle your affair amongst yourselves. We said: By God we shall go to 
them.... We reached them while they were assembled in the shed of Banu Sa'ida...there was a man who was wrapped in a cloak...I said: who is he? They said: Sa'd b.

'Ubādaā...a man among them stood up...and said...we are the Ansārs and the soldiers of Islam, and you are, O Quraysh the kinsfolk of our Prophet; and some of you migrated to us. He ['Umar] said: when I saw they wanted to downplay the root of our prominence, and usurp our leadership. I had prepared for myself words to say before of Abū Bakr... [but Abū Bakr spoke before me. He] did not leave anything I had intended to say without saying it or saying something better. He said: O Anșār; you are worthy of every virtue you mention; Arabs do not know this amr [leadership] to belong to one other than this quarter of Quraysh; they are the most honorable of all Arabs in locale and lineage....

When Abū Bakr finished talking, a man of them [Ansãr] stood up and said...from us a leader and from you a leader; O Quraysh...voices became louder and the babel increased...I ['Umar] said to Abū Bakr: Stretch out your hand so I would pledge allegiance to you. He stretched his hand so I pledged allegiance to him and Muhädjirūn and Ansār pledged allegiance to him. We then jumped on Sa'd, until one of them said: you killed Sa'd b. Ubada!...I said...By God we have not found a more important thing than pledging to Abu Bakr; we were afraid that had we parted with the people without pledging, they would have made a [different] pledge, then we would have had to either follow if we agreed, or disagree and then there would have been disintegration."alTTabari, Tarikh al-Tabari, III:70-72; see also Haroon, Tahdhīb Sī̄rat Ibn Hishām, 392394, where Ibn Hisham (d $828 \mathrm{CE}$ ) quotes a very similar narration to that quoted by alȚabari (d 932 CE), Ibn Hisham was almost a hundred years earlier than al-Ṭabari.

${ }^{128}$ Here is another narration of al-Tabari about what happened in the sakifa: According to a narration after Abd Allāh bin Abd al-Rahmān bin abi 'Umrah al-Ansārī, Abū Bakr said: '...We are the rulers and you are the ministers....' al-Hubāb b. alMundhir b. al-Djamūh said: O Anșar...if they [Muhājirūn] insist only on what you have heard [candidacy of Abú Bakr] then let there be from us a ruler and from them a ruler. Umār said: impossible, two swords can never combine in one sheath! By God, Arabs will not agree to give you the leadership while their Prophet is from a different locale; however, Arabs would not refuse to give leadership to those in whom prophethood took place... and in this we have a clear proof and authority against those of the Arabs who refuse and would dispute with us our claim to the sovereignty of Muhammad and his leadership, while we are his heirs and clan unless they are promoting falsehood, inclining towards sin, or involved in ruin...Abū Ubayda said: O Anșar; you are the first to aide and assist; do not be the first to renege and alter... Abū Bakr said: Here is Umar, and there is Abū Ubayda, pledge to either one you wish. They both said: No by God, we will not take on that before you. You are the best of the Muhadjirin and the second of two in the cave, and the one who succeeded him [in leading] prayers; and prayers are the most honored in the religion of Muslims; who should be ahead of you or take on the leadership before you! Stretch out your hand, so we could pledge allegiance to you." alȚabari, Tarikh al-Tabari, III:83-84.

${ }^{129}$ (Haroon, Tahdhīb Sī̄rat Ibn Hishām, 394-95. 
${ }^{130}$ See al-‘Ashmawī, Al-Khilafa al-Islamiyya, 169-170.

131 Thomas W. Arnold with a concluding chapter by Sylvia G. Haim. The Caliphate. (New York: Barnes \& Noble, Inc., 1966), 20.

132 The Qur'an is adamant about Muhammad being the last of the prophets and messengers of God: "33:40 [And know, O believers, that] Muhammad is not the father of any one of your men, but is God's Apostle and the Seal of all Prophets. And God has indeed full knowledge of everything" (The Qur'an).

133 This is a famous hadith. An abbreviated version of this hadith is in al-Bukhari: Ibn 'Umar said: "the Prophet of God (peace by upon him) said: 'I have been commanded to fight people until they say: there is no God but God, whoever says that he has secured himself and his wealth from me except for what is due, and his accountability to God."' Authenticated by Bukhari in Kitab al-Īmān: Hadith 25. Two other versions were authenticated by Muslim in Kitab al- İmān: Hadith 124; and Tirmidhi in Abwab al-Īmān: Hadith 2607. See Āl al-Sheikh, Mawsu'atu al-hadith al-sharīf, 4; 684;1914.

This hadith is problematic in spite of the strength of its chains of narration for it contradicts the Qur'anic verse 2:256 "There shall be no coercion in matters of faith. Distinct has now become the right way from [the way of] error: hence, he who rejects the powers of evil and believes in God has indeed taken hold of a support most unfailing, which shall never give way: for God is all-hearing, all-knowing" (The Qur'an). It also contradicts the practice of the Prophet. According to classical scholarship, any hadith that contradicts the Qur'an has to be rejected unless it could be validly reinterpreted in a way that would make it possible to reconcile with the Qur'an. For examples on this issue see my article: Wayel Azmeh. "Corporal Punishment Verses in the Qur'an are to be Reinterpreted to Counter Violent Extremist Practices from within the Islamic Juristic Tradition.” DOMES-Digest of Middle East Studies. 24.2 (2015): 161-186. Web. 2015.

${ }^{134}$ Arnold, The Caliphate, 45-46.

135 38:26 "[And We said:] 'O David! Behold, We have made thee a [prophet and, thus, Our] vicegerent on earth: judge, then, between men with justice, and do not follow vain desire, lest it lead thee astray from the path of God: verily, for those who go astray from the path of God there is suffering severe in store for having forgotten the Day of Reckoning!"' (The Qur'an).

136 24:55 God has promised those of you who have attained to faith and do righteous deeds that, of a certainty, He will cause them to accede to power on earth, even as He caused [some of] those who lived before them to accede to it; and that, of a certainty, He will firmly establish for them the religion which He has been pleased to bestow on them; and that, of a certainty, He will cause their erstwhile state of fear to be replaced by a sense of security [seeing that] they worship Me [alone], not ascribing divine powers to aught beside Me. But all who, after [having understood] this, choose to 
deny the truth - it is they, they who are truly iniquitous!" (The Qur'an); see Asad, The Message of the Qur'an, comment on 38:26.

137 This hadith was narrated in "Sunan Abu Dāwūd." al-Irbad ibn Sariyah narrated: AbdurRahman ibn Amr as-Sulami and Hujr ibn Hujr said: We came to Irbad ibn Sariyah who was among those about whom the following verse was revealed: "Nor is there blame on those who come to you to be provided with mounts, and when you said: I can find no mounts for you." We greeted him and said: "We have come to see you to give healing and obtain benefit from you." Al-Irbad said: "One day the Apostle of Allah (peace be upon him) led us in prayer, then faced us and gave us a lengthy exhortation at which the eyes shed tears and the hearts were afraid. A man said: 'Apostle of Allah! It seems as if it were a farewell exhortation, so what injunction do you give us?' He then said: 'I enjoin you to fear Allah, and to listen and obey even if it be an Abyssinian slave, for those of you who live after me will see great disagreement. You must then follow my Sunna and that of the rightly-guided caliphs. Hold to it and be steadfast. Avoid novelties, for every novelty is an innovation, and every innovation is an error." See All al-Sheikh, Mawsu'atu al-hadith al-sharīf, 1561.

138 The hadith was related in "Sunan Abu Dāwūd." Safinah narrated, The Prophet (peace be upon him) said: "The caliphate in the tradition of the Prophet will last thirty years; then Allah will give the reign to whomever He wills." See Āl al-Sheikh, Mawsu'atu al-hadith al-sharîf, 1564. 